\title{
BREAKING BAD? \\ Discarding THE Solutrean NORMS: CHRONOLOGY, EVOLUTION AND GEOGRAPHICAL EXtent of The BAdegoulian Phenomenon in Western Europe
}

\author{
Sylvain Ducasse $^{1}$, François-Xavier Chauvière ${ }^{2}$, Jean-Marc Pétillon ${ }^{3}$ \\ ${ }^{1}$ CNRS, UMR 5199 «PACEA», Université de Bordeaux, Bâtiment B2, Allée Geoffroy Saint-Hilaire, CS \\ 50023, 33615 Pessac Cedex, France. E-mail address: sylvain.ducasse@ u-bordeaux.fr. \\ ${ }^{2}$ Office du patrimoine et de l'archéologie du canton de Neuchâtel, section Archéologie, Laténium, Parc et musée \\ d'archéologie, Espace Paul Vouga, 2068 Hauterive, Switzerland. \\ ${ }^{3}$ CNRS, UMR 5608 «TRACES », Maison de la Recherche, 5, allées Antonio Machado, 31058 Toulouse Cedex \\ 9, France.
}

\begin{abstract}
The Badegoulian technocomplex holds a special place among the West European Upper Paleolithic (UP) cultural traditions. Often understated or even bypassed by the main prehistorical overviews, caught between the fascinating Solutrean and the "classic" Magdalenian technocomplexes, it nonetheless probably marks a turning point in the evolving trajectory of hunter-gatherers in present-day France. The deep typo-technological changes, traditionally noted through lithic equipment, have recently been examined in the framework of interdisciplinary programs centered on several key-stratigraphic sequences located in south-west France. The combined analyses of flint, bone and antler assemblages, ornaments and faunal remains, together with the implementation of systematic archaeostratigraphic reassessment and radiometric dating, serve to confirm the speed and the strength of these changes ca. 23 cal ka BP. Without going into detail into the Solutrean-Badegoulian transition issue, the present paper provides a synthetic overview of the main Badegoulian characteristics - and their known variability — on the basis of the lithic and osseous equipment that guided the original identification. Following a three-step structure successively exploring the "when", the "what" and the "where" questions, we will look at the current challenges in LGM chronocultural research, between (false) consensus and (true) sticking points.
\end{abstract}

KEYWORDS: Western Europe, France, Badegoulian, radiometric chronology, lithic and osseous industries, cultural geography

\section{INTRODUCTION}

From the very first descriptions by Capitan and Breuil (1902) to current research, the socalled Badegoulian technocomplex has raised several questions and sub-questions that still remain unsolved. Appearing to be the odd man out in the highly specific and codified universe of the West European Upper Paleolithic, the "unable" Badegoulian flintknapper (Breuil, 1937) broke the prehistorian codes when he broke the Solutrean ones. While the issue of the integration of the Badegoulian assemblages into the Magdalenian phylogeny has given rise to stronger debate (as notably shown through an endless terminological dispute; see for a summary Cretin, 2007 or Ducasse, 2010: 8-14), a fairly broad consensus quickly emerged concerning the strong break existing between the Upper Solutrean and the Badegoulian (e.g. Breuil, 1937; Cheynier, 1939; Allain and Fritsch, 1967; Allain, 1983).

Emphasized by the sudden disappearance of the main Solutrean typo-technological lithic markers-laurel-leaf and shouldered points as well as flat and invasive retouch - this shift was interpreted in several ways depending on the evolution of paradigms and the scientific "school of thought" within which studies took place. Thus, while the answer to the "why" has long been sought only in the effects of ancient migrations, sometimes giving rise to disruptive analogies (Cheynier, 1939, p. 395) or very questionable scenarios (Stanford and Bradley, 2002; O'Brien et al., 2014), the impact of past climatic and environmental variability is now preferred and is currently deeply explored, both to clarify its conjunction with - and possible role in - the "cultural" evolving processes and to discuss its effect on human dispersal and population dynamics (e.g. Banks et al., 2008; 2009; 2011; Burke et al., 2014; 2017). At the 
same time, the "where", sometimes strongly connected to the "when" and corresponding for decades to a major point of contention (e.g. Bosselin and Djindjian, 1999; 2000; Straus and Clark, 2000), still remains little understood, drastically limiting the viability of large-scale models. Similarly to the recognition of Badegoulian industries across the area of present-day France which was slow and progressive (Daniel, 1937; 1952; Cheynier, 1939; SonnevilleBordes, 1966; Sacchi, 1967; Clottes, 1989), resulting from various-and sometimes combined-factors (old excavations conducted with obsolete methods, unrecognized taphonomic issues, paradigmatic resistance, etc.: see below), discussions are still ongoing about the existence - and, if so, about the chronology-of the Badegoulian typo-technoeconomic norms outside the classic "French core", leading to deep interpretative divergences (this being notably the case in the Iberian Peninsula where the Final Solutrean hypothesis still challenges the Badegoulian one: e.g. Rios Garaizar et al., 2013; Zilhão, 2013; Straus, 2018; Rasilla Vives et al., 2019). These divergences, partly rooted in existing gaps in the archaeological record as well as in chronological uncertainties, are currently blurring a broad understanding of the Badegoulian issue, often making it difficult to discuss the crucial question of cultural geography objectively, since "regionalization" versus "globalization" phenomena (sensu Valentin, 2008, p. 72) are sometimes based on prehistorian rather than prehistoric "frontiers" (e.g. Cazals et al., 2007).

Rooted in recent and ongoing research conducted in the framework of several interdisciplinary programs (SaM project: S. Ducasse and C. Renard dir.; LA_BA project: S Ducasse and D. Sacchi dir), monograph projects (Clottes et al., 2012; Cassegros project: S. Ducasse and J.-M. Le Tensorer dir.; Casserole project: A. Lenoble and L. Detrain dir.; Chatenet project: S. Ducasse and Q. Villeneuve dir.), PhDs (Renard, 2010; Ducasse, 2010; Baumann, 2014; Peschaux, 2017) or standalone studies that have highlighted the general trend of techno- and socio-economic evolution from the Upper Solutrean to the Badegoulian in SW France (Ducasse et al., 2019b; Renard and Ducasse, 2015), this brief paper aims at refocusing on the Badegoulian technocomplex to perform an updated chronological, typo-technoeconomical and geographical state of the art. Results from archaeozoological and adornment studies will be set aside, and the following synthesis will be based only on lithic and osseous equipment from the "French core" area, following a three-step presentation: (1) the "when" will be explored first through the presentation of a renewed radiometric framework of the Badegoulian-type industries, (2) the "what" will then be recalled through a synthetic - and critical-view of the typo-technological and techno-economic characteristics and transformations of the flint, bone and antler industries and, from there, (3) the "where" and its implications will be challenged in the light of most recent research, especially regarding the current Solutrean-Magdalenian framework in Cantabrian Spain (e.g. Straus and Langlais, 2020), the relationship between Badegoulian and Salpetrian near the Rhône valley (Boccaccio and Bazile, 2008; Boccaccio, this volume) and the so-called Swiss Badegoulian (Le Tensorer, 1996; Sedlmeier, 2010; Leesch et al., 2012; Reade et al., 2020).

\section{MATERIAL AND METHODS}

The following overview is based on a total of 17 archaeological sites located from the north of the Aquitaine Basin to the Basque Country and the Languedoc region (figure 1 and table 1). Such a corpus, composed of assemblages encompassing the main part of the currently known Badegoulian typo-technological variability, together with a bibliographic review, provide an important and solid basis for discussing the above issues. While two-thirds of this corpus correspond to multi-layered deposits from caves $(\mathrm{N}=6)$ and rockshelters $(\mathrm{N}=5)$, the last third is composed of single-layered open-air sites $(\mathrm{N}=6)$; Twelve of the seventeen sites yielded well-preserved osseous component. Given that it includes sites that were excavated in very 
different time periods, ranging from the 1910s to the 2010s (table 1), we had to adapt our methodological approaches on a case-by-case basis to ensure that each studied sample was representative. To avoid repetitions and unnecessary developments, we refer to the detailed information and explanations of these adaptations given in princeps studies (see the references listed in table 1). While the analysis of lithic and osseous assemblages was carried out according to the well-known, classic typo-technological and techno-economic approaches (e.g. Geneste, 1991; Inizan et al., 1995; Pelegrin, 1995; 2000; Averbouh, 2010; Tixier, 2012), we have taken systematic steps to control the chronocultural homogeneity of each assemblage, including - when feasible and relevant - intra- and inter-layer refittings, as recommended in lithic taphonomy studies (Villa, 1982; Bordes, 2000; Klaric, 2003; Bertran et al., 2017), and extended to the bone and antler assemblages (Pétillon, 2006).

In order to further test the intra-site coherence as well as to optimize the inter-site and interregional comparisons, careful attention was also paid to the renewing of the radiometric framework. Thus, as detailed in previous publications (Ducasse et al., 2019b), the archaeostratigraphic reassessment of each site systematically included a chapter dedicated to the radiometric framework, whether it was to revise, update (e.g. Cuzoul de Vers rockshelter, Lot: Ducasse et al., 2014; Pégourié Cave, Lot: Ducasse et al., 2019a; Casserole rockshelter, Dordogne: Ducasse et al., 2020 or Lassac open air site, Aude: Pétillon and Ducasse, 2012) or create ex-nihilo solid chronological data (e.g. Cassegros rockshelter, Lot-et-Garonne: dataset of fourteen AMS ages for the Upper Paleolithic sequence, soon to be published). Depending on the specificities of each context, direct dating of 3D coordinated osseous manufactured artifacts was favored (i.e. bone and antler manufacturing technical wastes or finished tools and points: see e.g. Brou, 2006; Ducasse et al., 2014 for a detailed description of the sampling method), and completed - or substituted when direct dating of the osseous industry was not possible - by 3D coordinated faunal remains. In contrast, note that in the case of presumed unreliable (e.g. Pégourié Cave, Lot) or even lacking stratigraphic information (e.g. Les Harpons rockshelter, Haute-Garonne: Ducasse et al., 2017), faunal remains were generally excluded from the dating program which, in consequence, was quasi exclusively supplied by manufactured artifacts considered to be chronoculturally specific. In such contexts, only rare or non-usual species have been directly dated. In general, to ensure the inter-comparability of results, notably by reducing the impact of inter-laboratory variability in pretreatment processes, the samples to be dated were entrusted to a limited number of labs (i.e. ORAU lab of Oxford; Lyon-CDRC/Saclay-CEA in the framework of the ARTEMIS program: Billard, 2008; Lyon-CDRC/Groningen-CIO) and inter-laboratory blind-tests were-successfullyheld several years apart (2011-2017; ORAU versus Lyon/Saclay). All in all, such a strategy led to results that serve at different scales, shedding light on various aspects of the archaeological record, whether purely chronological (i.e. timing of the different stages of the Badegoulian technocomplex, from its first expressions to the very early manifestations of the Magdalenian features), typo-technological (i.e. charting the (micro-)evolution of the bone and antler equipment), environmental (i.e. reassessing the faunal species associations and their evolution) or taphonomical (i.e. by highlighting the potential chronocultural heterogeneity of the analyzed assemblages).

Finally, as shown in figure $1 \mathrm{~b}$, the studied sites can be divided into four main groups according to the level of reliability of each previously characterized Badegoulian assemblage and chronocultural attribution certainty: (1) sites with well-defined and well-preserved Badegoulian components (e.g. Cuzoul de Vers and Casserole rockshelters, Cabannes open-air site); (2) sites with well-defined Badegoulian components underlying previously unrecognized Magdalenian ones, leading to several typo-technological reattributions with respect to initial publication (e.g. Cassegros Cave); (3) mixed sites combining Badegoulian and other Upper Paleolithic components from which Badegoulian markers were separated, 
sometimes through direct dating in the specific case of osseous artifacts (e.g. Pégourié Cave, Le Piage and Les Harpons rockshelter), and (4) undatable, uncommon Badegoulian-like lithic assemblages (e.g. Bertonne core-yielding assemblages like the Seyresse open-air site: figure 1c). While dynamic restitutions of the Badegoulian lithic and osseous technical system, as well as the radiometric framework, were obviously based mainly on the two first categories, the third one allowed (or theoretically may allow) us to complement specific aspects of the Badegoulian typo-techno-economic features through the study of decontextualized lithic markers (i.e. petrographic analysis searching for long-distance raw material/toolkit diffusion; techno-functional analysis) and directly dated bone and antler artifacts (i.e. typo-technology of hunting equipment; specific decorations). As indicated above and developed below, the latter also served to discuss and complement the evolution trends of several typotechnological specificities. The cultural, chronological and possible functional statuses of the fourth and last group - corresponding in our study to the single case of Seyresse (table 1) but theoretically extendable to similar regional and extra-regional open-air sites (e.g. Lenoir, 1987; Ducasse and Langlais, 2008; Chehmana et al., 2010; Lafarge, 2014)—were examined through typo-techno-economic comparisons with assemblages from the two first groups (Ducasse, 2010: 395-403) and discussed in the present paper in the light of most recent advances (e.g. Primault et al., 2020).

\section{RESUlTS AND DisCUSSION}

\subsection{Searching for the tipping points: recent reassessment of the ${ }^{14} \mathrm{C}$ chronology}

The timing of the several "tipping points" punctuating the development of the Badegoulian technocomplex-mainly if not exclusively classically defined through the lithic equipment (i.e. Early and Late stages: Bordes, 1958; Trotignon et al., 1984; Morala, 1993; Fourloubey, 1998; Cretin et al., 2007; see below) — has undergone several profound changes over the past twenty years. These changes, stemming from new findings and research and from methodological improvements in dating processes (i.e. AMS dating, pretreatment process developments, etc.), sampling strategies (see above) and result interpretations (Ducasse et al., 2014; Banks et al., 2019), are mainly reflected in a global ageing and a chronological tightening, as first documented at Le Cuzoul de Vers rockshelter (Oberlin and Valladas, 2012). This dual phenomenon has affected our understanding of local/regional issues as well as inter-regional and inter-cultural comparisons (see below, section 3.3).

A reassessed radiometric framework is presented in figure 2 and table 2, based on a nonexhaustive but representative dataset of $45{ }^{14} \mathrm{C}$ AMS ages from the available corpus collected in the framework of the above-mentioned projects conducted in SW France (table 2, \#1-27, 41-45; see above), supplemented by a selection of recently published ages from (1) reliable Badegoulian sequences or sites located in Dordogne, Poitou, Bourgogne and Massif Central, and (2) a series of compatible Badegoulian ages from disturbed assemblages yielding clear Badegoulian component ("Badegoulian-like" tagged ages: table 2, \#37-40, 44-45). Note that this selection does not include compatible ages from sites for which the cultural attribution is still pending (e.g. Montoya et al., 2019) or any beta counting ages, since it has been demonstrated that a number of problems exist regarding their comparability with recent AMS ages (i.e. bulk samples giving average results, high standard-deviations, etc.: Ducasse et al., 2020; Banks et al., 2019).

Finally, the results of this reassessment have led to a switch from the 22,8-19 cal ka BP interval that was documented at the end of the 1990s through the combination of several betacounting dated key-sites from the Paris Basin to the Languedoc region (e.g. Cuzoul de Vers, layer 24: 18,400 $\pm 200 \mathrm{BP}, 22,8-21,9$ cal ka BP, Gif-6798; Lassac, locus 1: 16,750 \pm 250 , 
20,8-19,6 cal ka BP, Gif-2981; Cuzoul de Vers, layer 5c: 15,980 $\pm 150,19,6-18,9$ cal ka BP, Gif-6638), to a 2,000-year interval approximately comprised between 23,5/23 cal ka BPoverlapping with the most recent Upper Solutrean ages - and 21/20,5 cal ka BP (figure 2). These results, obtained from the same geographical area or even the same sites, show that contrary to the prevailing general view (Bosselin and Djindjian, 1997; Djindjian, 2000), the chronological gap hypothesis is unable to explain the deep and sharp break documented between the Upper Solutrean and the Early and Late Badegoulian assemblages (e.g. Renard and Ducasse, 2015). As we can see, these changes, the possible causes of which are beyond the scope of this paper, took place during a relatively short-term phase characterized by high climatic instability (GI2.2-GS2.2-GI2.1: Rasmussen et al., 2014, pp. 17, 22). From there, the Badegoulian covers the first part of the Last Glacial Maximum (LGM, sensu Mix et al., 2001; MARGO Project members, 2009) corresponding to cold and humid conditions (GS2.1c). At the opposite chronological milestone, the Badegoulian-to-Magdalenian transition timespan, i.e. 21,5-20,5 cal ka BP (not illustrated in figure 2), is currently being much discussed through the ongoing characterization of the so-called LDDM industries (named after the presence of specific marginally retouched bladelets called "Lamelles à Dos Dextre Marginal": Langlais et al., 2010; Ducasse et al., 2011) in the framework of the DEX_TER project (S. Ducasse and M. Langlais dir.; see below). Finally, between these two limits, the issue of the classic two-fold division between Early and Late Badegoulian-quite wellestablished in term of archaeostratigraphic sequence - appears to be chronologically blurred by the strong overlap visible within the 23,5-22,5 cal ka BP timespan, corresponding to the entire development of the Early stage, as documented at Le Cuzoul de Vers (layers 27 to 22: Ducasse, 2010; Clottes et al., 2012) and Casserole rockshelters (layer NA6: Ducasse et al., 2020; Morala, 1993).

However, besides this general and paradigm-dependent framework, and despite a too low radiometric resolution for these clearly fast phenomena, we will see that detailed archaeostratigraphic examinations of the timing and co-evolution of several typotechnological proxies reveal a very complex but exciting panorama.

3.2. Refining the core definition of the Badegoulian: characteristics and evolution of its technical equipment

\subsection{1. "Punk rocks": an overview of Badegoulian flint technology}

The triumph of technical mediocrity never happened: research carried out for more than twenty-five years in present-day France has unequivocally demonstrated that the Badegoulian lithic technical system, by breaking the Upper Solutrean rigid norms, paved the way to a noless innovative cycle. The apparent simplicity of these flake-dominated industries is in some ways what makes them so complex to fix in a single picture, since simplicity gives way to versatility, adaptability and then variability. While previous syntheses, aiming at discussing the general framework of the Solutrean-to-Badegoulian transition in SW France, took the side of an average - and thus necessary simplified - presentation (Ducasse et al., 2019b; Renard and Ducasse, 2015), the following lines will focus on specific and sometimes exceptional points in order to serve subsequent diachronic views. Pending the results of an ongoing $\mathrm{PhD}$ work focusing on the technical exploitation of "non-flint" components from Upper Solutrean and Badegoulian lithic assemblages (Q. Villeneuve; University of Bordeaux), only the flint component will be considered.

The Early Badegoulian (ca. 23 cal ka BP): nothing will be the same again 
Although the classic Early Badegoulian (EB) features (e.g. Allain and Fritsch, 1967; Gaussen, 1980; Trotignon et al., 1984; Clottes and Giraud, 1989; Morala, 1993) were sometimes seenrightly in certain cases - as the result of non-chronological but functional variability or issues in the representativeness of the considered archaeological record (e.g. Bodu et al., 2007), it has finally been firmly demonstrated from recently excavated archaeological sequences that specific raclette-less Badegoulian-like assemblages systematically pre-date the well-known raclette-yielding assemblages (i.e. no evidence of Early Badegoulian/Late Badegoulian-like assemblage interstratification). However, a critical review of the so-called Early Badegoulian suggests that extremely few known assemblages can safely be attributed to this first chronocultural stage (see Ducasse, 2010, pp. 376-382 for a detailed reassessment). To date, there are between four and five taphonomically-reliable sites that could fit with such an attribution, from the strongest stratified evidence (Le Cuzoul de Vers, Lot, layer 27 to 22; Casserole NA6, Dordogne) to the undated but fully compatible ones (Fritsch rockshelter, Indre, layer 6 to 8b: Trotignon et al., 1984; Aubry et al., 2007; Le Péhau, Gironde: Monin, 2014; Pasquini et al., 2014). While a clear EB component is documented at Cassegros Cave, Lot-et-Garonne (Le Tensorer, 1981 and obs. pers.), it remains extremely difficult to distinguish from the Late Badegoulian one, according to recent work to be published in the framework of the ongoing monograph project (Ducasse and Le Tensorer dir.). Despite the numerous recognized layers mostly based on sedimentary variations, the EB sequence of Le Cuzoul de Vers, on which the information below is essentially based, must be taken as a twophase (if not one-phase) sequence, since inter-layer refittings were clearly documented between layers 27 and 24 (e.g. figure 3, \#5, figure 4a, \#3 and figure 4b, \#2) and suspected for layers 23 and 22. For its part, Casserole NA6 is demonstrated to be a single and highly coherent assemblage (Morala, 1993 and obs. pers.).

Taken alone, the main typo-technological lithic features of the EB illustrate, more than any "average" view of Badegoulian flint technology (Renard and Ducasse, 2015), the very strong disruption occurring after the Upper Solutrean (US) in France. Thus, while the toolkits are mainly composed of "domestic" tools, among which thin and sometimes short ones bearing semi-abrupt retouches should be noted (figure 3, \#6-7; i.e. proto-raclettes sensu Le Tensorer, 1981), they are lacking in undisputed evidence of lithic tips and inserts potentially involved in hunting activities. Few unretouched (micro-)bladelets are documented and come essentially from flake-edge cores (i.e. part of the so-called "notched burins": figure 4a, \#3) while "carinated" reduction sequences are extremely rare, if not absent, within the studied EB assemblages (note that such reduction sequences were described as part of the AMS-undated lowermost Badegoulian $\square \mathrm{EB}$ ? $\square$ assemblages from the Fritsch rockshelter, together with a unique marginally-retouched microbladelet: Aubry et al., 2007). This absence of backed or retouched specimens cannot be viewed in relation to a representativeness bias since the finefraction lithic material (i.e. retouch flakes, chips, micro-debris: Ducasse, 2010, p. 194) is well documented, notably at Le Cuzoul de Vers thanks to the implementation of quasi systematic water sifting (Clottes et al., 2012). Lastly, the possible role of the numerous sharp blanks obtained from flint bipolar reduction in the manufacturing and use of hunting equipment remains difficult to state in the absence of use-wear analysis (Ducasse, 2010, pp. 221-224).

That being said and besides the versatile role and status of the well-documented bipolar percussion, the main techno-economic aspects of the studied EB assemblages can be summarized and simplified as follows: (1) a marked exploitation of the local lithic resources together with the limited but systematic contribution of regional and extra-regional raw material through (2) the introduction of blade tools (with evidence of soft organic percussion) or robust blanks, the latter to be used as "domestic" tools or edge core-blanks, (3) the in situ and marginal implementation of blade production, simplified and adapted to local raw materials (figure $4 a, \# 1$ ), together with (4) the massive implementation of flake production to 
obtain a wide range of blanks, from thick flakes to thin and/or elongated ones; for the most part these flakes are from integrative/multi-objective productions, sometimes organized in distinct and successive short sequences.

Further ongoing and subsequent collective analyses of Le Cuzoul de Vers EB assemblages, including archaeostratigraphic and technological analyses of the numerous available refittings, a study of the "non-flint" component ( $\mathrm{PhD}$ work of Q. Villeneuve, see above) as well as a renewed petrographic approach and the implementation of use-wear analyses will, in the medium term, increase our understanding of these very rare pieces of evidence of one of the major tipping points in the evolution of West European Upper Paleolithic traditions.

\section{"One shot": the Badegoulian shouldered points (ca. 23-22,5 cal ka BP)}

Apart from the demonstrated cases of cultural admixtures with Solutrean components (e.g. Pégourié Cave, Lot: Ducasse et al., 2019a; Le Piage, Lot: Champagne and Espitalié, 1981; Bordes et al., 2006), assemblages from Le Cuzoul de Vers, layers 16 to 21 are the only demonstrated example to date of a raclette-yielding industry containing shouldered points (figure $5 \mathrm{a}$ and $5 \mathrm{~b}$ ). Contrary to what is suggested by the multi-layered distribution of these specific artifacts, archaeostratigraphic analyses and inter-layers refittings have shown that this typo-technological combination probably corresponds to a "one-shot" phenomenon (Ducasse, 2010; Ducasse et al., 2014). Since the main typological and techno-economic features of these assemblages are quite comparable to the ones from uppermost levels, we will not repeat here what was previously published in the same journal (see Ducasse, 2012).

The corpus of 37 specimens, found in association with several invasive-backed bladelets (figure 5a, \#11-14), is characterized by a large number of fragmented pieces showing diagnostic impact fractures and scars. Besides the use of local alluvial flints, this typological group documents the use of a wide variety of raw materials among which non-determined allochtonous flints are frequent: with a single exception (figure 5a, \#7 and 10), each point comes from distinct exploited volumes. This high degree of spatial-temporal techno-economic fragmentation makes it difficult to accurately characterize the implemented schema opératoire. Moreover, the high morphometric variety of the blanks used could suggest-at least partly - distinct technological origins. A technological assessment of the industries from layers 16 to 20 has notably shown evidence of (1) in situ unipolar production of small, thin and narrow rectilinear blades (figure 5a, \#9; soft mineral percussion) compatible with the lowretouched shouldered points, and (2) spatially and temporally segmented blade reduction sequences from opposite platform cores, potentially partially implemented in situ (figure 5a, \#8) but essentially visible through imported artifacts. Beyond the implementation of systematic direct or crossed abrupt retouch, this technological diversity is coupled with strong typological variability. However, a subgroup distinguishes itself despite a non-systematic lateralization (figure 5a, \#1 and 2): opposing a generally long and narrow tang to a short limb, these artifacts bear an indirect and short retouch at the proximal end (probably used to reduce the convexity of the butt) which shapes a specific "coma-like" extremity recalling the Salpetrian shouldered points (Bazile and Boccaccio, 2008 and Boccaccio, this volume) and thus fueling an inter-regional and inter-cultural connection hypothesis that will be discussed later in this paper.

Although the techno-economic features of these hunting weapons' production (i.e. on-site production together with imported cores and/or finished points) theoretically suggest links with regional/extra-regional raclette-yielding occupations, a careful consideration of reliable southwestern assemblages reveals an almost complete absence of similar typo-technological evidence. Beside the undatable Late Badegoulian open-air site of Cabanne, Landes, which yields evidence of compatible imported thin rectilinear blades, together with a single possible 
backed point (interpretation to be confirmed through use-wear analysis; Ducasse, 2010: 318), the isolation of the assemblages from Le Cuzoul de Vers, layers 16 to 21, may also reflects the under-representation of the archaeological records for the 23-22,5 cal ka BP timespan (see below).

\section{On the edge: the issue of raclette-yielding Badegoulian (micro-)bladelet production}

Contrary to the shouldered point-yielding assemblages, the Late Badegoulian bladelet productions are essentially linked to ramified chaînes opératoires through the exploitation of thick flakes and, occasionally, robust blades. Three distinct schemas opératoires are currently recognized to be part of the Badegoulian technical palette: (1) flake-edge cores aka "notched burins" producing bladelets, microbladelets and robust lamellar flakes (Bodu et al., 2007; Bodu and Chehmana, 2008; Ducasse, 2010; 2012); (2) "sur front dorsal" cores, aka "carinated enscrapers" producing microbladelets (see Ducasse and Langlais, 2007 for terminological information), and (3) "Orville/Bertonne" cores mainly producing specific bladelets with a "fluted-facet" (Ducasse and Langlais, 2008; Chehmana et al., 2010; Ducasse, 2010; Chehmana, 2011). While flake-edge cores sensu lato are almost systematically part of the Late Badegoulian assemblages, whatever the considered space of time and geographical area, the chronological distribution of the two other technical modalities are currently fueling specific issues that deserve further developments.

Regarding the "sur front dorsal" cores - which were classically considered to be among the markers of the Badegoulian, partly justifying the comparison with Aurignacian featuresresearch carried out in recent years have shown their great scarcity, if not absence, within taphonomically-controlled assemblages from caves and rockshelters (e.g. Le Cuzoul de Vers: Ducasse, 2010; Casserole rockshelter and Cassegros Cave: obs. pers.), as well as their questionable association with Badegoulian components within disturbed archaeological records (e.g. Pégourié Cave: Ducasse et al., 2019a, Le Petit Cloup Barrat, Lot) or collections from surface surveys. In the latter case, note that a recurring association between raclettes and very specific Aurignacian-like "nosed" cores is documented in the Gironde region-notably seen at Birac III and Le Pourquey open-air sites (Crochet, 1967; Sireix, 1988; pers. obs.) and is the object of ongoing critical reassessment. Finally, until this problem is resolved, the only reliable Badegoulian cases where the implementation of microbladelet production through "sur front dorsal" cores is clearly developed correspond to (1) undatable open-air sites (e.g. Mirande 2, Tarn-et-Garonne: Langlais et al., 2016) and (2) assemblages that can be chronologically assigned to the end of the Badegoulian, ca. 22-21 cal ka BP (e.g. Lassac locus 1, Aude: Ducasse, 2010; Oisy-Mont Saint Aubin, Nièvre: Bodu et al., 2007), both associated with direct and/or inverse backed microbladelets (figure 6).

From the seminal work of Lenoir (1976) and Perlès (1982) to the systematic revisions from old collections and the recently published evidence from Le Taillis-des-Coteaux, Vienne (Primault et al., 2020), the chronocultural issue of the "Orville/Bertonne"-type productions seems close to a resolution. While the technological status of Bertonne pieces as bladelet cores was firmly established through convergent research (Ducasse and Langlais, 2008; Chehmana et al., 2010), their chronological distribution and cultural attribution is still pending (see Ducasse, 2010, pp. 396-403 for an extended overview). Although the authors remain cautious regarding the reliability of the documented association of raclette and Orville/Bertonne cores within Le Taillis-des-Coteaux assemblages from levels AGIIIf and AGIIIg (Primault et al., 2020), this exceptional stratified and dated evidence (21,8-20,9 cal ka BP) places Orville-dominated industries within the Badegoulian-to-Magdalenian transition phase. This, combined with (1) the associated Badegoulian-like antler technology (i.e. use of the knapping technique; Pétillon and Ducasse, 2012), (2) the undisputable association of 
Bertonne cores with Badegoulian-type components from recently excavated open-air sites and highly reliable raclette-yielding assemblages (e.g. Cabannes, Landes: Gellibert and Merlet, 2001; Ducasse, 2010; Les Sablons, Gironde: Ortega et al., 2005; Cretin et al., 2007), and (3) the more questionable but similar association from Lassac (Ducasse, 2010, pp. 400), appears to be consistent with a development (if not an emergence) at the very end of the Late Badegoulian.

\subsubsection{Badegoulian to the bone: a revised typo-technological framework for the osseous industries}

Despite the precocity of the work of Allain and Rigaud at the Fritsch rockshelter, Indre (Allain et al., 1974; Rigaud, 2004), and the significant role of antlerworking in the individualization of the Badegoulian technocomplex (e.g. Rigaud, 1989, p. 215), little was known about the technological aspects of the Badegoulian osseous equipment, notably in the Aquitaine basin, despite the fact that sites yielding manufactured bone and antler artifacts are abundant in this region (e.g. Laugerie-Haute and Lachaud rockshelters, Dordogne: Bordes, 1958 and Cheynier, 1965; Cassegros Cave, Lot-et-Garonne: Le Tensorer, 1981). Apart from the unpublished work of P. Bidart at Casserole rockshelter, Dordogne (Detrain et al., 1992), it was only at the end of the 2000s and the work of J.-M. Pétillon and A. Averbouh at Le Cuzoul de Vers rockshelter, Lot (Averbouh and Pétillon, 2011; Pétillon and Averbouh, 2012) that this part of the archaeological record was finally systematically reconsidered, on a large-scale basis (table 1) and in a consistent manner. Regarding technology, this work confirmd and supplemented the proposal of Allain and Rigaud: while the use of the groove and splinter technique (GST) to produce antler blanks has since been suggested based on evidence from Pégourié Cave, Lot (Séronie-Vivien, 1995), and from the open-air site of Lassac, Aude (Sacchi, 2003; artifacts from surface surveys and poorly documented sectors of the site), a critical analysis coupled with direct ${ }^{14} \mathrm{C}$ dating has shown that the knapping technique was the only method used to produce antler splinters during the Badegoulian (figure $7 \mathrm{a}$ and $\mathrm{b}$; Ducasse et al., 2019a; in press; Pétillon and Ducasse, 2012; Pétillon and Chauvière, 2017). As can be seen in figure 2 ("K"-tagged ages), directly-dated flakes $\square$ similar to those represented in figure $7 \mathrm{a}, \# 1 \square$ or other specific knapping waste products are distributed all along the Badegoulian timespan, from 23,6 to 20,7 cal ka BP (table 2, \#9 and \#41; note that the only known counterexample comes from the Lascaux Cave and has recently been discussed in the framework of a new dating program: Ducasse and Langlais, 2019).

Considering the taphonomically-controlled assemblages, the so-called "domestic" component of the osseous toolkits is not very diversified and is mainly composed of tools involved in the working of organic materials (the only significant exception being bone retouchers, which correspond to ubiquitous Paleolithic tool types that are well represented in Badegoulian assemblages as well). Specifically, besides bone awls, the Badegoulian assemblages are marked by the significant presence of bone-eyed needles (figure 7c, \#3 and 4). As previously noted, while the appearance of bone-eyed needles during the Upper Solutrean in SW France still needs clarification, the early stages of the Badegoulian witnessed their first clear development and generalization in Western Europe, indicating the deployment of new dressmaking techniques (Pétillon and Chauvière in Ducasse et al., 2019b; Pétillon and Chauvière, 2017). It is worth stating that no evidence of the use of GST for the exploitation of bones has been documented to date and the implementation of alternative methods consisting in the scraping, abrasion and polishing of cortical fragments from medium-size ungulate diaphysis has been suggested based on Le Cuzoul de Vers assemblages and unpublished experimental tests (Le Guillou, 2012, p. 352). Antler beveled tools (i.e., chisel/wedge types) are rare, except at Cuzoul de Vers where they are represented by a number of highly curated, 
fully shaped artifacts (figure 7c, \#5). Antler perforated batons (bâtons percés) are absent and bone spatulas (lissoirs) are very scarce.

Compared to Middle and Upper Magdalenian standards (Langley et al., 2016) and contrary to the stereotype of the poorly-dated and probably mixed assemblages of the Placard Cave, the Badegoulian projectile points from recently excavated and/or reliable sites appear to be relatively rare, and mostly non-decorated. This scarcity is coupled with a marked diversity that seems to be, at least in part, chronologically ordered according to the results of direct ${ }^{14} \mathrm{C}$ dating and archaeosequence comparisons (figure 2 and 8; see below). Right after the extremely small and poorly characterized Early Badegoulian assemblages ca. 23,5-23 cal ka BP (Le Guillou, 2012; Pétillon and Averbouh, 2012), self-barded antler points (figure 7c, \#2; Le Cuzoul de Vers, ca. 22,5 cal ka BP) are documented and may have continued until the end of the period, while single-beveled points with round or oval cross-sections, including striated beveled points (figure 7c, \#6 and 7; "SsBP" and "Pe"-tagged ages in figure 2; e.g Pégourié Cave, 22,5-21,5 cal ka BP), are only documented at a later stage after ca. $22.5 \mathrm{cal} \mathrm{ka}$ BP. The three parallel longitudinal and curvilinear lines motif, carved with the so-called "pseudoexcise" technique (Barandiarán, 1973; Utrilla, 1986), is currently the only decoration undeniably specific to the Badegoulian in SW France, as firmly demonstrated through the direct dating of the specimen from Pégourié (figure 7c, \#6 and "Pe"-tagged age in figure 2; Ducasse et al., 2019a). Note that the issue of the possible Badegoulian attribution of the famous but enigmatic "arciform artifacts" from the Placard Cave (Chauvière et al., 2017) some of them bearing Lascaux-like motifs (e.g. Feruglio and Leroy-Prost, 2001) — needs to be further discussed in the light of ongoing research; indeed, attribution to the LDDM-yielding industries (see above) cannot be ruled out.

\subsubsection{Challenging the classic two-fold chronocultural division? A first essay}

While much is yet to be done and published, results achieved over the past twenty years already allow for a refinement, if not a reconsideration, of the low-significant and singleproxy framework, mostly based on a few typological lithic markers. While this is not to say that the classic two-fold division based on the emergence of raclette-yielding assemblages remains meaningless, the multiplication and combination of elements from both lithic and osseous equipment show subtle and sometimes differentiated developments, justifying new proposals. As presented in figure 8, the chronological distribution of weaponry items (i.e. backed bladelets, lithic and osseous points) as well as some of their related technological aspects (i.e. blank production modalities) give us a glimpse of potential typo-technological (micro-)evolutions to be further tested through subsequent analysis. From a short, indivisible and currently little-represented Early Badegoulian stage (see above), the variability of the raclette-yielding assemblages, aka Late Badegoulian, shows several specificities that, along its whole timespan (23-21 cal ka BP), emerged and developed in an arrhythmic way. Inequivalent in length and occurrences, non-dependent on functional and regional variability (Ducasse, 2012; Ducasse et al., 2019b) and sometimes chronologically overlapped despite a well-differentiated stratigraphic position (Ducasse et al., 2014), this possible evidence of internal evolutions can be summarized as follows:

(1) Early Badegoulian (EB; 23,5-23 cal ka BP): unchanged classic first stage, quite rare at the currently known Badegoulian distribution area (see above); EB is marked by very poor bone and antler assemblages within which the typology of the-scarcehunting equipment remains unclear; apart from extremely rare and sometimes doubtful (micro-)bladelet cores ("sur front dorsal" and core-edge modalities) together with possible, but a not clearly demonstrated production of edged debris from flint bipolar 
reduction (Ducasse, 2010), retouched lithic toolkits are only composed of a wide variety of "domestic" tools (see above);

(2) Late Badegoulian, aka raclette-yielding industries (LB; 23-20,5 cal ka BP): if it is premature to speak of real sub-stages within the LB timespan, the fact remains that a general trend has appeared through the combination of archaeostratigraphic and radiometric data from several French assemblages (e.g. Le Cuzoul de Vers, Casserole, Le Taillis-des-Coteaux, Lassac, Oisy), as well as evidence from directly-dated artifacts. Thus, the following proposition, comprising three empirical clusters, should only be considered as a future line of work.

? The oldest currently known LB assemblages, previously only documented at Le Cuzoul de Vers rockshelter (layers 21-16), are marked from around 23 cal ka BP by the technologically coherent but currently unique association between a classic Badegoulian "domestic" component-including numerous typical raclettes - and abruptly-retouched shouldered points, together with backed bladelets (invasive back) sometimes obtained from the same reduction sequences (see above); both categories show diagnostic features of use as projectile elements. As in the EB case, almost no bone or antler points are documented. Although this assemblage may theoretically correspond to a specific expression of the synchronic variability of raclette-yielding assemblages, it is factual to point out its specific chronological position in terms of both stratigraphic and radiometric evidence.

?.While the 23-22 cal ka BP interval is currently little-documented through dated sequences (see figure 2) and, once again, essentially known at Le Cuzoul de Vers (layers 15-6 at least), the lithic equipment shows marked similarities with numerous undated SW France assemblages, since it corresponds to very "classic" Badegoulian ones (i.e. flake tools including raclettes, blade tool-kit, (micro-)bladelet production on edge cores; unretouched bladelets); opposite the underlying shouldered point assemblages, unequivocal hunting points are this time made of antler, as essentially seen through the development of thin bipoints, among which laterally-beveled pieces can be considered as self-barbed points.

? The last part of the LB $(22-20,5$ cal $\mathrm{ka}$ BP $)$ is both the best radiometricallydocumented (figure 2 and table 2) and probably the most complex timespan. Thus, while the so-called "Final Badegoulian" stage, traditionally marked by the development of Magdalenian-like typo-technological components (e.g. SéronieVivien, 1995; Le Tensorer, 1996), is no longer considered relevant as initially defined (Pétillon and Ducasse, 2012; Ducasse et al., 2019b), the 22-20,5 time range nevertheless shows an increasing diversification of lithic and osseous hunting equipment. Whereas raclette and backed microbladelet-yielding assemblages are clearly documented (e.g. Oisy, Nièvre, layers 3 and 4: Bodu et al., 2007; Bodu and Chehmana, 2008; Debout et al., 2012; Lassac, Aude, locus 1: Ducasse, 2010), direct dating of specific antler artifacts from disturbed assemblages yielding Late Badegoulian components suggests that single and striated beveled points-aka Placard-type points sensu Aura et al., 2012; Utrilla Miranda et al., 2020 —emerged from about 22,5 cal ka BP and may have developed at least until 21,5 ka cal BP together with the famous "pseudo-excised" decorations (Ducasse et al., 2019a) and the persistence of self-barbed points (e.g. in Pégourié). To date, the end of the LB-and thus the Badegoulian-to-Magdalenian transition-remains highly unclear and archaeostratigraphic records often contradict inter-site radiometric comparisons. This is notably the case considering the timing of the emergence of marginally right sideretouched bladelets in the context of Bertonne/Orville pieces-yielding assemblages and LDDM industries, both still pending clear chronocultural attribution. 
This arrhythmic typo-technologic chronology should be complemented and challenged in the short and long term, not only through an increase in radiometric data from taphonomicallycontrolled sequences (e.g. Fritsch rochshelter, Indre) and/or directly dated characteristic artifacts (e.g. the famous "Lower Magdalenian" antler tools and points from Le Placard Cave, Charente, or Lachaud rockshelter, Dordogne), but also in light of more detailed technoeconomic data (e.g. evolution of the spatio-temporal management of lithic tool-kits), ornament variability and faunal dynamics, in order to better weigh the reality and significance of these evolution and, subsequently, to turn this simple timeline into an animated panorama. Above all, we have to keep in mind that these phenomena could have had distinct chronological and geographical realities, leading us to the final question to be addressed in this paper: to what extent do the "what" and the "when" detailed above, essentially based on the classic "French core" assemblages, dissolve when the "where" is examined?

\subsection{A purely "French" phenomenon?}

From this chronocultural model, the never-ending question of the "where" must be addressed through a multiscale approach, not only outside the present-day France, but also closer to the classic "Badegoulian core", by reassessing its margins on a step-by-step basis and with an open mind. While the current geographical distribution of the French Badegoulian is now very similar to the previous Upper Solutrean one, going far beyond the initial Perigord area (figure 1a), recent discoveries and studies in northern France (e.g. Le Chemin de l'Evangile 3, Yonne: Connet et al., 2004, 2019; Le Colombier, Aisne: Montoya et al., 2019) suggest a possible greater "cultural" complexity-unless it reflects undocumented techno-economic complementarities - showing that a binary presence-absence test is far from relevant here. Furthermore, it is likely that considering the chronological variability highlighted above, the Badegoulian margins should rather be seen as shifting boundaries. That being said and pending further extra-regional data, results obtained in SW France can be used to complement and discuss, if not challenge a part of the established frameworks. From the strongest evidence to that pending, the following and last sections will briefly consider the issue of "cultural geography" in three different directions, corresponding, as we will see, to three distinct phases.

\subsubsection{The Vasco-Cantabrian connection: tracking "pseudo-excised" artifacts}

The alleged scarcity, if not absence, of Badegoulian industries in the French Pyrenees has long been considered the result of an anthropological phenomenon: the specific concavebased points-yielding Upper Solutrean assemblages, unknown to the north, were in direct cultural and chronological continuity with the Vasco-Cantabrian ones, which, according to some, developed until the emergence of Magdalenian societies around 20,5 cal ka BP. This model must be reconsidered in depth, since it has recently been demonstrated that this absence on the north side of the Pyrenees is due to a strong bias in the available archaeological collections (i.e. extremely old excavations essentially by R. de Saint-Périer from the 1910s to the 1930s) that in fact yield clear but unnoticed Late Badegoulian lithic and osseous elements mixed with Upper Solutrean (US) components (Ducasse et al., 2017). In view of these elements and considering the proposed terminus ante quem of $23 \mathrm{cal} \mathrm{ka} \mathrm{BP}$ for the Pyrenean US (op. cit.), it seems reasonable to call into question the chronology of the concave-based points-yielding US assemblages in Vasco-Cantabrian Spain-mostly based on old betacounting ages - and, in doing so, the absence of Badegoulian in this area. Following the seminal work of Utrilla (1986) and the discoveries made fifteen years ago by Fortea at Llonín, 
Asturias (Fortea Pérez et al., 1995; Duarte et al., 2014; Rasilla Vives et al., 2019), recent research has been conducted on two successive and interdependent fronts to look further into the issue of the Cantabrian Badegoulian: (1) to confirm through undisputed evidence the Badegoulian attribution of the French so-called "pseudo-excised" antler artifacts since all of them derive from old-excavated and/or taphonomically-questionable sequences (Ducasse, 2010, p. 360) and, subsequently (2) to track this potential Badegoulian "signal" by reviewing the "pseudo-excised" piece-yielding assemblages from present-day Spain. While the first objective has been successfully completed, as shown earlier (see section 3.2.2), through the reassessment of the Pégourié Cave sequence and the direct dating of the unique specimen of "pseudo-excise" decorated antler point (see section 3.2.2; Ducasse et al., 2019a), the second one was addressed through the typo-technological and archaeostratigraphical reassessment of the Solutrean-Magdalenian sequence of Aitzbitarte IV, Basque Country. This work, conducted in 2018 and 2019, allowed us to obtain a final confirmation of the Utrilla hypothesis through the identification of unequivocal Badegoulian lithic markers (figure 9) whose relative stratigraphic distribution, compared to the Upper Solutrean and Middle/Upper Magdalenian components, is still being addressed.

While the details of this latter evidence and its implication will be discussed in depth in a dedicated paper (Ducasse and Ruiz-Redondo, in prep), it is important to stress here that, coming on top of the Llonín and Pégourié radiometric data (22,5-20,5 cal ka BP), it adds significant fuel to the hypothesis of the existence of a cultural network that extended from the north of the Aquitaine Basin to Asturias, at least during the second part of the Late Badegoulian stage (Ducasse et al., 2019a). This is at least what is suggested by the archaeostratigraphic, chronological and typo-technological evidence from Llonin, level III (figure 8; Ducasse et al., 2019a): overlying a 23,5-23 cal ka-dated concave-base pointyielding Upper Solutrean industry (table 3, \#7-9), this well-dated assemblage (22,4-20,9 cal ka BP; table 3, \#1-6) bears highly characteristic raclettes together with several single and striated beveled antler points (i.e. Placard-type points) and evidence of the use of the "pseudoexcise" technique to engrave antler artifacts (Rasilla Vives et al., 2019; Duarte et al., 2014).

\subsubsection{What about the Badegoulian-Salpetrian relationship?}

The hypothesis of a partial synchrony between Badegoulian and Salpetrian (Bazile and Boccaccio, 2008; Boccaccio, this volume), implying the existence of a marked cultural geography independent of any obvious physical/environmental barrier, currently rests on (1) the alleged "post-Upper Solutrean" position of the Salpetrian (op. cit.); (2) the existence of abruptly-retouched shouldered lithic points-a Salpetrian marker (see Boccaccio, this volume) - within classic raclette-yielding Badegoulian assemblages from Le Cuzoul de Vers, Lot (see above, layers 21-16); and (3) recent ${ }^{14} \mathrm{C}$ AMS ages for the eponymous site of La Salpêtrière, Gard (Bazile, 2014, p. 12). Although this assumption is theoretically relevant, several elements, including big weaknesses in the available archaeological record, require a cautious approach. Thus, without invalidating the above model, we can theoretically discuss or challenge it as follows:

- There is no reliable archaeological sequence documenting the transition between the Upper Solutrean and the Salpetrian: Upper Solutrean is lacking at La Salpêtrière (Bazile, 1990; Boccaccio, 1999) and other Salpetrian assemblages are from undatable single-layered open-air sites (Boccaccio, 2006a; 2006b; Bazile and Boccaccio, 2008);

- Upper Solutrean is poorly documented in the Rhône valley, both typo-technologically and chronologically: Baume d'Oullins (Bazile and Bazile-Robert, 1979) is the only known evidence, yielding Salpetrian-type shouldered points together with "pointes à 
face plane" (Bazile and Boccaccio, 2007) suggesting a possible mix between Early Solutrean and Salpetrian components;

- Evidence of Salpetrian-type shouldered points within Upper Solutrean assemblages is documented and vice versa: as pointed out by G. Boccaccio (2005, p. 458), scarce but clear evidence from Le Fourneau-du-Diable, Dordogne, shows high typotechnological similarities with Salpetrian standards; similarly, the Salpetrian assemblage of the La Rouvière open-air site, Ardèche, gave a typical Atlantic-type Upper Solutrean shouldered point manufactured with flat and invasive retouch applied on a non-Salpetrian blank (Boccaccio, 2005, p. 231); note that the raw material used to produce the latter artifact was potentially acquired from the Turonian outcrops of the Cher valley (Delvigne et al., 2017);

- The archaeological succession between Salpetrian and raclette-yielding Badegoulian is known at the Petite Grotte de Bize, Aude: despite the limitation of these old excavations (see table 1), Bize provides a unique relative chronology confirming this succession; the challenge is now to give an age to this transition in order to know if it occurred prior to the emergence of Lassac-type assemblages ca. 21,5 cal ka BP (figure 2 and 6b; ongoing research in the framework of the LA_BA project, Ducasse and Sacchi dir.);

- The Badegoulian shouldered points show very distinct-and variable-typotechnological standards compared to the strict Salpetrian ones (see above, section 3.2.1): besides the strong typological divergences, opposite technological choices were selected: while in the Salpetrian a strong technical investment concerned the production of very morphometrically calibrated blanks that were then marginally transformed, the Badegoulian strategy follows the opposite logic consisting in producing less standardized blanks that were finally very shaped;

- The initial beta counting radiometric framework highlighted two distinct chronological phases: a 1,000-year gap between the shouldered point-yielding Badegoulian (layer 20; Gif-6797: 17,050 \pm 170 BP, i.e. 20,971-20,186 cal ka BP) and the Salpetrian (layer d; MC-2084: 18,500 \pm 240 BP, i.e. 22,966-21,990 cal ka BP) was recorded;

- Finally, despite the obtaining of new ${ }^{14} C A M S$ ages, the strong radiometric overlaps seen in figure 2 between undisputable successive chronocultural phases in SW France (i.e. Upper Solutrean/Early Badegoulian/Lower Late Badegoulian) urge caution when it comes to dealing with long-distance radiometric comparisons.

All in all, and to take the discussion one step further, one could provocatively ask whether the Languedocian Salpetrian would not in fact correspond to one of the numerous regional and specific expressions of the Upper Solutrean. Such a hypothesis, which might sound extreme, does not contradict the possibility that a partial cultural overlap could have occurred from the Aquitaine to the Rhone valley during the timespan corresponding to the very beginning of the (Early) Badegoulian. In any event, we must accept the current limitation of the archaeological record, which is unable to provide definitive conclusions: significant advances can never be made without refreshed fieldwork data.

\subsubsection{Were there raclettes in Switzerland?}

The most easterly Badegoulian-like evidence in present-day France remains poorly documented and known only through compatible radiometric ages, generally deriving from anciently excavated sites (Cupillard et al., 2015; Béreiziat, 2020; figure 1a). This evidence likely corresponds to Late Badegoulian components, as is probably the case at Solutré (Saône- 
et-Loire) in the Upper Solutrean layer 3 of sector I11, where tools bearing abrupt retouches "similar to that observed on the Ancient Magdalenian [=Badegoulian] raclettes" (Combier and Montet-White, 2002, p. 77) are documented, together with several 21 cal ka BP-centered beta-counting ages inconsistent with the Upper Solutrean component (see Ducasse et al., 2017, pp. 264-265). While the existence of discrete Bertonne/Orville bladelet productions at La Roncière, Côte-d'Or (Soriano and Lechenet, 2000) and Rigney, Doubs (Malgarini et al., 2017) cannot be sufficiently conclusive, recent AMS ages from La Baume-Noire-Fretigney, level M5, provide interesting evidence of human occupations around 23,5-23 cal ka BP (Béreiziat, 2020): despite an uncharacterized assemblage to date, this timespan not only corresponds to the Solutrean-to-Badegoulian transition phase in SW France (see above and Ducasse et al., 2019b), but also to the recently refined chronological framework of the middle archaeological layer from Kastelhöhle Nord cave (Switzerland; table 3, \#10-12), for which a Badegoulian attribution has long been proposed (Le Tensorer, 1996; Street and Terberger, 1999; Sedlmeier, 2010; Leesch et al., 2012). Long — and still—considered as the Badegoulian entrance gate in present-day France from Central Europe according to older ages compared to the now obsolete beta-counting chronology of Le Cuzoul de Vers (e.g. Terberger, 2013, pp. 437-439), this industry actually shows strong similarities with the extremely rare Early Badegoulian assemblages documented in the Quercy and Dordogne regions (Morala, 1993; Ducasse, 2010; see above, figure 3, 4 and 8). While the lithic and osseous hunting tips or inserts are completely lacking, the "domestic" toolkits appear to be essentially composed of heavily retouched massive flakes and laminar flakes (end-scrapers, side-scrapers, etc.), together with semi-abruptly retouched thin flakes and numerous splintered pieces showing a (long and) complex use-life (i.e. "recycled" tools) (Sedlmeier, 2010). Pending a necessary direct and deeper comparison of these specific industries, the newly reassessed AMS radiometric frameworks of Le Cuzoul de Vers (Ducasse et al., 2014), Casserole NA6 (Ducasse et al., 2020) and Kastelhöhle Nord (Reade et al., 2020; table 3) allow one to propose a synchronic emergence and development from about 23,5 cal ka BP, thus complicating the relevant but still debated "Central Europe" hypothesis (i.e. population moves from East to West) initially based on a supposed "time-lag" (inferred from beta-counting and AMS ages comparisons) and an average typo-technological view of the Badegoulian typo-technological features. From this chronological readjustment and in parallel with the current chronocultural reassessment of Central and Eastern LGM assemblages (e.g. Neugebauer-Maresch et al., 2016; Škrdla et al., 2016; Demidenko et al., 2019), new typo-technological bases for such a discussion are currently being established and we consider that mid-term research efforts will probably be crucial.

\section{Conclusions}

Though non-exhaustive, this short overview serves not only to highlight the main evolutionary trends of LGM hunter-gatherer equipment from SW France, but also to point out, between the lines, all the gaps, deficiencies and other blind spots that punctuate our dataset and thus imbue our models. Setting aside the emergence and disappearance issues, the above synthetic chronocultural view restates, if necessary, that there is not a single "Badegoulian", but several ones, far beyond the classic EB/LB dichotomy. Although it might seem a risky enterprise given the missing data and radiometric inaccuracies for certain periods of time and/or some specific types of industries, this unprecedented chronological panorama provides typo-technological outlines to be further tested within and outside the classic French core area.

Taking advantage of recent and ongoing dynamic research on several key French LGM sequences, the combined "taphonomic"/typo-technological/radiometric approach developed 
here serves to define clear and exclusive chronological associations, as well as to identify blind spots for which further information is needed in order to strengthen the proposed framework. While the well-known-but not always fully understood-variability of Badegoulian equipment could partly be explained through (1) the specific techno-economic structuration of its lithic technical system (see Ducasse, 2010; 2012) and (2) (micro-)evolving dynamics as defined above, the remaining part of this variability is theoretically still to be discussed with an open mind through the lens of potential functional/regional/inter-cultural dynamics and/or currently undemonstrated/unspecified taphonomic issues. Among these blind spots and besides the burning issues of long-distance inter-regional-inter-cultural?relations (see above, section 3.3), the end of the Late Badegoulian (21,5-20,5 cal ka BP), including the Badegoulian-to-Magdalenian transition phase, deserves detailed investigation. In spite of (or perhaps because of) a dense archaeological record, it now appears to be a highly diverse and arrhythmic phase, where the "what" and the "when" issues are both difficult to precisely determine, most notably because the available archaeostratigraphic and radiometric resolutions remain problematic. While ongoing projects serve to reassess a significant portion of key anciently-excavated sites from SW France (e.g. DEX_TER and LA_BA projects, see above), the complementary contribution of ongoing and recent excavations (e.g. Primault et al., 2020) remains essential to weigh up the obtained results, exceed the methodological and paradigmatic limits of ancient collections, and open new perspectives.

Moreover, in parallel with the necessary acquisition of new fieldwork data to illuminate the particularly poorly understood chronological and/or geographical expressions of the Badegoulian (e.g. Bertonne-yielding assemblages; relationship between Salpetrian and Badegoulian in Languedoc; Solutrean-to-Badegoulian transition in the Pyrenees), efforts will have to be made, when possible, to adopt a systematic combined petrographic/typotechnological/functional approach to the lithic components, in parallel with detailed use-wear analyses of the antler and bone "domestic" equipment. Only such an approach will avoid the interpretative traps of the complex issue of synchronic versus diachronic variabilities and achieve more dynamic knowledge of the anthropologic phenomena studied.

All in all, the "whys" of the changes we observed in this paper remain the crucial issue, so future research should first conscientiously try to fill all these gaps in order to reduce, as far as possible, the background noise. Let's get to work!

\section{Acknowledgements}

SD is very grateful to Andreas Maier and Christoph Mayr for inviting him to their very interesting workshop at the wonderful Wiesenthau castle. A big thank-you to Yuri Demidenko and Petr Škrdla for the impromptu discussion in front of the amazing Mohelno-Plevovce lithic assemblage. Thanks to Guillaume Boccaccio, Andreas Maier, György Lengyel, Thomas Terberger, Alvaro Arrizabalaga, Olivier Moine, Pierre Antoine and Damien Rius for formal and informal discussions. Gyuri and Andreas: I sincerely hope that the post-Covid World will not prevent us too long from having our multi-postponed "Badegoulian" meeting! Many thanks to Antony Sécher for the last-minute cartographic assistance and to William Banks for its one-off language assistance. We thank the three anonymous reviewers whose comments served to strengthen the paper. Finally, SD would like to express its deepest thanks to Haude "Magic Flute" Morvan: à charge de revanche!

\section{Funding}

Most of this synthetic overview benefited from research carried out as part of several projects funded by the Direction Régionale des Affaires Culturelles d'Occitanie et de Nouvelle Aquitaine (Ministère de la Culture et de la Communication, France) between 2012 and 2019. The English proofreading (Hancock Hutton Langues Services) was funded by the PACEA laboratory.

\section{References}


Allain, J., 1983. Matériaux pour l'étude du "Magdalénien initial” et de ses origines. Bull. Soc. Préhist. Fr. 80, 135-139.

Allain, J., Fritsch, R., 1967. Le Badegoulien de l'abri Fritsch aux Roches de Pouligny-Saint-Pierre (Indre). Bull. Soc. Préhist. Fr. 64, 83-93.

Allain, J., Fritsch, R., Rigaud, A., Trotignon, F., 1974. Le débitage du bois de renne dans les niveaux à raclettes du Badegoulien de l'abri Fritsch et sa signification. In: Camps-Fabrer H. (Ed.), L'industries de l'os dans la Préhistoire. Premier colloque international sur l'industrie de l'os dans la Préhistoire, Abbaye de Sénanque, Avril 1974, pp. 67-71.

Allard, M., 1992. Les Magdaléniens de l'abri des Peyrugues à Orniac (Lot). Leur culture et leurs relations avec le milieu. In: Rigaud J.-P., Laville H., Vandermeersch B. (Eds.), Le peuplement magdalénien. Paléographie physique et humaine, actes du colloque de Chancelade, 10-15 octobre 1988, Comité des Travaux Historiques et Scientifiques (Documents préhistoriques 2), Paris, pp. 377-385.

Aubry, Th., Almeida, M., Chehmana, L., Thiennet, H., Walter, B., 2007. De la fin du Solutréen au Magdalénien moyen dans les vallées de la Claise et de la Creuse. Bull. Soc. Préhist. Fr. 104, 699-714.

Aura, J.E., Tiffagom, M., Jordá Pardo, J.F., Duarte, E., Fernández de la Vega, J., Santamaría Álvarez, D., Rasilla, de la, M., Vadillo Conesa, M., Perez Ripoll, M., 2012. The Solutrean-Magdalenian transition: A view from Iberia. Quat. Int. 272-273, 75-87. doi:http://dx.doi.org/10.1016/j.quaint.2012.05.020

Averbouh, A., 2010. Technologie de la matière osseuse travaillée et implications palethnologiques : l'exemple des chaines d'exploitation du bois de cervidé chez les magdaléniens des Pyrénées. University of Paris 1-Panthéon Sorbonne, unpublished $\mathrm{PhD}$ dissertation.

Averbouh, A., Pétillon, J.-M., 2011. Identification of "debitage by fracturation" on reindeer antler: case study of the Badegoulian levels at the Cuzoul de Vers (Lot, France). In: Baron, J., Kufel, B. (Eds.), Written in Bones : Studies on Technological and Social Contexts of Past Faunal Skeletal Remains. Uniwersytet Wrocławski - Instytut Archeologii, Wroclaw, pp. 41-51.

Banks, W.E., d'Errico, F., Peterson, A.T., Vanhaeren, M., Kageyama, M., Sepulchre, P., Ramstein, G., Jost, A., Lunt, D., 2008. Human ecological niches and ranges during the LGM in Europe derived from an application of eco-cultural niche modeling. J. Archaeol. Sci. 35, 481-491. doi:10.1016/j.jas.2007.05.011

Banks, W.E., Zilhão, J., d'Errico, F., Kageyama, M., Sima, A., Ronchitelli, A., 2009. Investigating links between ecology and bifacial tool types in Western Europe during the Last Glacial Maximum. J. Archaeol. Sci. 36, 2853-2867. doi:10.1016/j.jas.2009.09.014

Banks, W.E., Aubry, T., Errico, F. d', Zilhão, J., Lira-Noriega, A., Townsend Peterson, A., 2011. Eco-cultural niches of the Badegoulian: Unraveling links between cultural adaptation and ecology during the Last Glacial Maximum in France. J. Anthropol. Archaeol. 30, 359-374. doi:16/j.jaa.2011.05.003

Banks, W.E., Bertran, P., Ducasse, S., Klaric, L., Lanos, P., Renard, C., Mesa, M., 2019. An application of hierarchical Bayesian modeling to better constrain the chronologies of Upper Paleolithic archaeological cultures in France between ca. 32,000-21,000 calibrated years before present. Quat. Sci. Rev. 220, 188214.

Barandiarán, I., 1973. Arte mueble del Paleolitico Cantabrico, Monografias arqueologicas, Talleres Editoriales Libreria General, Zaragoza.

Baumann, M., 2014. À l'ombre des feuilles de laurier... ...Les équipements osseux solutréens du sud-ouest de la France. Apports et limites des collections anciennes. University of Paris 1-Panthéon Sorbonne, unpublished $\mathrm{PhD}$ dissertation.

Bazile, F., 1990. Le Solutréen et l'Épisolutréen dans le sud-est de la France. In: Kozlowky, J. (Ed.), Feuilles de pierre: les industries à pointes foliacées du Paléolithique supérieur européen, actes du colloque de Cracovie, 1989, ERAUL 42, pp. 393-423.

Bazile, F., 2014. Le bassin méditerranéen du Rhône: un carrefour de traditions culturelles au Tardiglaciaire (Programme "TARMED”), Etudes Quaternaires Languedociennes.

Bazile, F., Bazile-Robert, E., 1979. Le Solutréen à pointes à cran de la Baume d'Oullins (Le Garn, Gard, Labastide-de-Virac, Ardèche). Etudes préhist. 15, 1-6.

Bazile, F., Boccaccio, G., 2007. Du Solutréen supérieur au Magdalénien en Languedoc rhodanien. Ruptures et continuités. Bull. Soc. Préhist. Fr. 104, 787-796.

Bazile, F., Boccaccio, G., 2008. Le Salpêtrien ancien : un technocomplexe épisolutréen redéfini. Gall. Préhist. 50, 103-141. doi:10.3406/galip.2008.2459

Béreiziat, G., 2020. Par-delà les frontières. Discussion autour des « oscillations » des cadres chronoculturels du Magdalénien entre Rhône et Danube. In: Straus L.G., Langlais M. (Eds.), Magdalenian Chronostratigraphic Correlations and Cultural Connections between Cantabrian Spain and Southwest France... and beyond, actes de la Séance de La Société préhistorique Française, Séances de la Soc. Préhist. Fr. 15, Paris 2018. Société préhistorique française, Paris, pp. 163-184. 
Bertran, P., Bordes, J.-G., Todisco, D., Vallin, L., 2017. Géoarchéologie et taphonomie des vestiges archéologiques: impacts des processus naturels sur les assemblages et méthodes d'analyse. In: J.-P. Brugal (Ed.), TaphonomieS, Sciences Archéologiques, Paris, pp. 125-166.

Billard, C., 2008. Le programme ARTEMIS : nouvel outil pour la datation radiocarbone AMS (Spectromètre de Masse par Accélérateur) et nouvelles problématiques. In Situ. Revue des patrimoines. doi:10.4000/insitu.3342

Boccaccio, G., 1999. Le Salpêtrien ancien de la grotte de la Salpêtrière (Remoulins, Gard) : technologie du débitage. Bull. Soc. étud. sci. nat. Nîmes et Gard 62, 125-136.

Boccaccio, G., 2005. Les industries lithiques du Solutréen supérieur et du Salpêtrien ancien en Languedoc: ruptures et continuités des traditions techniques. Université de Provence - Aix-Marseille I, unpublished $\mathrm{PhD}$ dissertation.

Boccaccio, G., 2006a. Analyse technologique du débitage au Salpêtrien ancien : l'exemple du campement de la Rouvière à Vallon-Pont-d'Arc (Ardèche). Ardèche Archéol. 23, 6-15.

Boccaccio, G., 2006b. Le gisement salpêtrien de plein-air de Cadenet à Gaujac, Gard. Rhodanie 2-13.

Boccaccio, G., Bazile, F., 2008. Les industries lithiques de la fin du Solutréen et du Salpêtrien ancien : Apports de l'étude technologique à la compréhension de l'évolution culturelle au Pléniglaciaire en Languedoc (France). In: Aubry T., Almeida F., Araújo A.C., Tiffagom M. (Eds.), Space and Time: Which Diachronies, Which Synchronies, Which Scales?/Typology vs. Technology, actes du XVe Congrès International de l'UISPP, Sections C64 et C65, Lisbonne, 4-9 septembre 2006, BAR International Series 1831, pp. 177-187.

Bodu, P., Chehmana, L., 2008. Le Badegoulien du Bassin parisien présente-t-il des «caractères régressifs »? Réflexions à partir de l'étude du gisement de plein air du Mont-St-Aubin à Oisy (Nièvre, France). In: Aubry T., Almeida F., Araújo A.C., Tiffagom M. (Eds.), Space and Time: Which Diachronies, Which Synchronies, Which Scales?/Typology vs. Technology, actes du XVe Congrès International de l’UISPP, Sections C64 et C65, Lisbonne, 4-9 septembre 2006, BAR International Series 1831, pp. 167176.

Bodu, P., Chehmana, L., Debout, G., 2007. Le Badegoulien de la moitié nord de la France. Un état des connaissances. Bull. Soc. Préhist. Fr. 104, 661-680.

Bordes, F., 1958. Nouvelles fouilles à Laugerie-Haute Est : premiers résultats. L'Anthropol. 62, $205-244$.

Bordes, J.-G., 2000. La séquence aurignacienne de Caminade revisitée: l'apport des raccords d'intérêt stratigraphique. The Aurignacian sequence at Caminade Est revisited : contribution of the refittings to stratigraphie study. Paleo 12, 387-407. doi:10.3406/pal.2000.1611

Bordes, J.-G., Lebrun-Ricalens, F., Castel, J.-C., Ducasse, S., Faivre, J.-P., Feruglio, V., Henry-Gambier, D., Lacrampe-Cuyaubère, F., Laroulandie, V., Lenoble, A., Martin, H., Maureille, B., Morala, A., Renard, C., Rendu, W., Rigaud, S., Rougier, H., Tartar, E., Texier, P.-J., Teyssandier, N., 2008. Les débuts du Paléolithique supérieur dans le Sud-Ouest de la France: fouilles 2004-2006 au Piage (Fajoles, Lot). Problématique et premiers résultats. In: Jaubert J., Bordes J.-G., Ortega I. (Eds.), Les sociétés du Paléolithique dans un Grand Sud-Ouest de la France: nouveaux gisements, nouveaux résultats, nouvelles méthodes, Journée SPF, Université de Bordeaux I, Talence, 24-25 novembre 2006, Mémoire de la Soc. Préhist. Fr. 47, Société préhistorique française, Paris, pp. 261-288.

Bosselin, B., Djindjian, F., 1997. Une révision du Solutréen de Laugerie-Haute et le problème des transitions Gravettien-Solutréen et Solutréen-Badegoulien en Aquitaine. Bull. Soc. Préhist. Fr. 94, 443-454.

Bosselin, B., Djindjian, F., 1999. Une révision de la séquence de la Riera (Asturies) et la question du Badegoulien cantabrique. Bull. Soc. Préhist. Fr. 96, 153-173.

Bosselin, B., Djindjian, F., 2000. La question du Badegoulien cantabrique : réponse à L.G. Strauss et G.A. Clark. Bull. Soc. Préhist. Fr. 97, 297-307.

Breuil, H., 1937. Les subdivisions du Paléolithique supérieur et leur signification, Congrès international d'anthropologie et d'archéologie préhistoriques. Compte rendu de la XIVe session. Genève, 1ère édition 1912 (2ème édition, complétée et retouchée).

Bronk Ramsey, C., 2020. OxCal 4.4 manual [Internet]. Available from: https://c14.arch.ox.ac.uk/oxcalhelp/hlp_contents.html

Brou, L., 2006. Protocole de datation d'objets manufacturés en matière dure animale. In: Sacchi D., Langlais M. (dir.), Chronologie et Faciès du Magdalénien Méditerranéen, Rapport Intermédiaire, Service Régional d'Archéologie Languedoc-Roussillon, Montpellier, pp. 5-10.

Burke, A., Levavasseur, G., James, P.M.A., Guiducci, D., Izquierdo, M.A., Bourgeon, L., Kageyama, M., Ramstein, G., Vrac, M., 2014. Exploring the impact of climate variability during the Last Glacial Maximum on the pattern of human occupation of Iberia. J. Hum. Evol. 73, 35-46. doi:10.1016/j.jhevol.2014.06.003

Burke, A., Kageyama, M., Latombe, G., Fasel, M., Vrac, M., Ramstein, G., James, P.M.A., 2017. Risky business: The impact of climate and climate variability on human population dynamics in Western 
Europe during the Last Glacial Maximum. Quat. Sci. Rev. 164, 217-229. doi:10.1016/j.quascirev.2017.04.001

Capitan, L., Breuil, H., 1902. Une fouille systématique à Laugerie-Haute, Bulletin de l'Association Française Pour l'Avancement Des Sciences, 31ème session. Montauban, 9 août 1902, pp. 771-773.

Castel, J.-C., Chauvière, F.-X., L’Homme, X., Camus, H., 2006. Un nouveau gisement du Paléolithique supérieur récent: le Petit Cloup Barrat (Cabrerets, Lot, France). Bull. Soc. Préhist. Fr. 103, 263-273. https://doi.org/10.3406/bspf.2006.13432

Cazals, N., Batlle, X.T., Urquijo, J.E.G., 2007. Frontières naturelles et frontières culturelles dans les Pyrénées préhistoriques, actes de la table-ronde de Tarascon-sur-Ariège, 2004, Université de Cantabrie, Santander.

Champagne, F., Espitalié, R., 1981. Le Piage : site préhistorique du Lot, Mémoire de la Soc. Préhist. Fr. 15, Société préhistorique française, Paris.

Chauvière, F.-X., Castel, J.C., Ducasse, S., Langlais, M., Renard, C., 2017. L'attribution chronoculturelle des « objets arciformes » du Paléolithique supérieur: apports de la datation directe de l'ébauche du Petit Cloup Barrat (Cabrerets, Lot, France) et discussion autour de l'hypothèse badegoulienne. Bull. Soc. Préhist. Fr. 114, 619-635.

Chehmana, L., 2011. La méthode Orville: une invention badegoulienne ? Bull. Soc. Préhist. Fr. 108, 7-25. doi:10.3406/bspf.2011.13990

Chehmana, L., Holzem, N., Pelegrin, J., Bazin, P., 2010. La fonction des pièces de la Bertonne : un problème en partie résolu. Paleo 21, 65-102.

Cheynier, A., 1939. Le Magdalénien primitif de Badegoule, niveaux à raclettes. Bull. Soc. Préhist. Fr. 36, 334 396.

Cheynier, A., 1965. L'abri Lachaud à Terrasson (Dordogne). Presses Universitaires de France, Paris.

Clottes, J., 1989. Le Magdalénien des Pyrénées. In: Rigaud J.-P. (Ed.), Le Magdalénien en Europe. La structuration du Magdalénien, actes du colloque de Mayence organisé dans le cadre du XIe Congrès de l'UISPP, 1987, ERAUL 38, pp. 289-341.

Clottes, J., Giraud, J.-P., 1989. Le gisement préhistorique du Cuzoul (Vers, Lot). Quercy Recherche 65-66, 8291.

Clottes, J., Chalard, P., Giraud, J.-P., 2012. Solutréen et Badegoulien au Cuzoul de Vers : des chasseurs de rennes en Quercy, ERAUL 131, Liège.

Combier, J., Montet-White, A., 2002. Solutré 1968-1998, Mémoire de la Soc. Préhist. Fr. 30, Société préhistorique française, Paris.

Connet, N., Lhomme, V., Chaussé, C., Bémilli, C., 2004. Le Chemin de l'Évangile 3 à Gron (Yonne). Une occupation du Paléolithique supérieur ancien dans la vallée de l'Yonne. Bull. Soc. Préhist. Fr. 101, 2744. doi:10.3406/bspf.2004.12946

Connet, N., Bemilli, C., Chaussé, C., Claud, E., Dayet, L., Vanhaeren, M., 2019. Par un début de printemps du Dernier Maximum Glaciaire, le site du "Chemin de l'Evangile 3" à Gron (Yonne, France). In: Montoya C., Fagnard J.-P., Locht J.-L. (Eds.), Préhistoire de l'Europe du Nord-Ouest : mobilité, climats et entités culturelles, actes du 28ème Congrès Préhistorique de France, Session $\mathrm{n}^{\circ} 2$, Palethnologie du Paléolithique supérieur ancien: où en sommes-nous ? Amiens, 30 mai-4 juin 2016, Société préhistorique française, Paris, pp. 165-184.

Cretin, C., 2007. “Arrêt sur” le Badegoulien. Historique, état de la question et perspectives. In: Evin J. (Eds), Un siècle de construction du discours scientifique en Préhistoire, congrès du centenaire de la Société préhistorique française, Avignon, 21-25 septembre 2004, Société préhistorique française, Paris, pp. 367-378.

Cretin, C., Ferullo, O., Fourloubey, Ch., Lenoir, M., Morala, A., 2007. Le Badegoulien du nord de l'Aquitaine : de nouveaux moyens de lecture. Bull. Soc. Préhist. Fr. 104, 715-734.

Crochet, J.-Y., 1967. Le Magdalénien I de Birac, commune de St Sulpice-et- Cameyrac Gironde). Bull. Soc. Préhist. Fr. 64, 100-107.

Cupillard, C., Magny, M., Bocherens, H., Bridault, A., Bégeot, C., Bichet, V., Bossuet, G., Drucker, D.G., Gauthier, E., Jouannic, G., Millet, L., Richard, H., Rius, D., Ruffaldi, P., Walter-Simonnet, A.-V., 2015. Changes in ecosystems, climate and societies in the Jura Mountains between 40 and 8 ka cal BP. Quat. Int. 378, 40-72. doi:10.1016/j.quaint.2014.05.032

Daniel, R., 1937. L'industrie du niveau inférieur de la station de Beauregard, près de Nemours (Seine-et-Marne), n’est pas aurignacienne ; elle doit être classée à la base du Magdalénien. Bull. Soc. Préhist. Fr. 34, 239254.

Daniel, R., 1952. Le proto-Magdalénien. Bull. Soc. Préhist. Fr. 49, 274-278.

Debout, G., Olive, M., Bignon, O., Bodu, P., Chehmana, L., Valentin, B., 2012. The Magdalenian in the Paris Basin: New results. Quat. Int. 272-273, 176-190. doi:10.1016/j.quaint.2012.05.016 
Delvigne, V., Fernandes, P., Piboule, M., Lafarge, A., Raynal, J.-P., 2017. Circulation de géomatières sur de longues distances au Paléolithique supérieur : le cas des silex du Turonien du Sud du Bassin parisien. C. R. Palevol 16, 82-102. doi:10.1016/j.crpv.2016.04.005

Demidenko, Y.E., Škrdla, P., Rios-Garaizar, J., 2019. In between Gravettian and Epigravettian in Central and Eastern Europe: a Peculiar LGM Early Late Upper Paleolithic industry. Přehled výzkumů 60, 11-42.

Detrain, L., Kervazo, B., Aubry, Th., Bourguignon, L., Guadelli, J.-L., Marcon, V., Teillet, Ph., 1991. Agrandissement du Musée National de Préhistoire des Eyzies : résultats préliminaires des fouilles de sauvetage. Paleo 3, 75-91.

Detrain, L., Aubry, Th., Beyer, C., Bidart, P., Bourguignon, L., Diot, M.-F., Guadelli, J.-L., Kervazo, B., Legrand, Y., Leroyer, C., Limondin, N., Marcon, V., Morala, A., Platel, J.-P., Rouzo, P., 1992. Fouilles préliminaires à l'agrandissement du Musée National de Préhistoire des Eyzies, 1991-1992. AFAN.

Djindjian, F., 2000. Identité, chronologie et territoires du Magdalénien en Europe occidentale : questions posées. In: Pion G. (Ed.), Le Paléolithique supérieur récent: nouvelles données sur le peuplement et l'environnement, acte de la Table Ronde de Chambéry, 12-13 mars 1999, Mémoire de la Soc. Préhist. Fr. 28, Société préhistorique française, Paris, pp. 95-112.

Duarte, E., Rasilla, de la, M., Aura, J.-E., 2014. La técnica pseudoexcisa en el Badeguliense / Magdaleniense arcaico de Asturias. Arch. de Pehist. Levantina XXX, 27-55.

Ducasse, S., 2010. La "parenthèse" badegoulienne: fondements et statut d'une discordance industrielle au travers de l'analyse techno-économique de plusieurs ensembles lithiques méridionaux du Dernier Maximum Glaciaire. University of Toulouse 2, unpublished $\mathrm{PhD}$ dissertation. https://tel.archivesouvertes.fr/tel-00565784/fr/

Ducasse, S., 2012. What is left of the Badegoulian "interlude"? New data on cultural evolution in southern France between 23,500 and 20,500 cal. BP. Quat. Int. 272-273, 150-165. doi:10.1016/j.quaint.2012.05.018

Ducasse, S., Langlais, M., 2007. Entre Badegoulien et Magdalénien, nos cœurs balancent... Approche critique des industries lithiques du Sud de la France et du Nord-Est espagnol entre 19000 et 16500 BP. Bull. Soc. Préhist. Fr. 104, 771-786.

Ducasse, S., Langlais, M., 2008. Interprétation technologique et discussion autour du statut culturel des "pièces de la Bertonne". L'exemple de la série lithique de Seyresse (Landes, France). Paleo 20, 59-88.

Ducasse, S., Langlais, M., 2019. Twenty years on, a new date with Lascaux. Reassessing the chronology of the cave's paleolithic occupations through new 14C AMS dating. Paleo 30,1, 130-147.

Ducasse, S., Pétillon, J.-M., Chauvière, F.-X., Renard, C., Lacrampe-Cuyaubère, F., Muth, X., 2019 a. Archaeological recontextualization and first direct 14C dating of a "pseudo-excise" decorated antler point from France (Pégourié Cave, Lot). Implications on the cultural geography of southwestern Europe during the Last Glacial Maximum. J. Archaeol. Sci. Rep. 23, 592-616. doi:10.1016/j.jasrep.2018.11.019

Ducasse, S., Renard, C., Baumann, M., Castel, J.C., Chauvière, F.-X., Peschaux, C., Pétillon, J.-M., 2019b. Pour une palethnologie du pauvre: apports des séquences du Sud-Ouest de la France à la définition des comportements techno- et socio-économiques lors de la transition solutréo-badegoulienne. In: Montoya C., Fagnard J.-P., Locht J.-L. (Eds.), Préhistoire de l'Europe du Nord-Ouest : mobilité, climats et entités culturelles, actes du 28ème Congrès Préhistorique de France, Session $\mathrm{n}^{\circ} 2$, Palethnologie du Paléolithique supérieur ancien: où en sommes-nous? Amiens, 30 mai-4 juin 2016, Société préhistorique française, Paris, pp. 117-140.

Ducasse, S., Pétillon, J.-M., Aubry, T., Chauvière, F.-X., Castel, J.C., Detrain, L., Langlais, M., Morala, A., Banks, W.E., Lenoble, A., 2020. The Abri Casserole (Dordogne, France): Reassessing the 14C Chronology of a Key Upper Paleolithic Sequence in Southwestern France. Radiocarbon. doi: 10.1017/RDC.2020.50

Ducasse, S., Castel, J.-C., Chauvière, F.-X., Langlais, M., Camus, H., Morala, A., Turq, A., 2011. Le Quercy au cœur du dernier maximum glaciaire. Paleo 22, 101-154.

Ducasse, S., Pétillon, J.-M., Renard, C., 2014. Le cadre radiométrique de la séquence solutréo-badegoulienne du Cuzoul de Vers : lecture critique et compléments. Paleo 25, 37-58.

Ducasse, S., Renard, C., Pétillon, J.-M., Costamagno, S., Foucher, P., Foucher, C., Caux, S., 2017. Les Pyrénées au cours du Dernier Maximum Glaciaire. Un no man's land badegoulien? Nouvelles données sur l'occupation du piémont pyrénéen à partir du réexamen des industries solutréennes de l'abri des Harpons (Lespugue, Haute-Garonne). Bull. Soc. Préhist. Fr. 114, 257-294.

Ehlers, J., Ehlers, J., Gibbard, P.L., Hughes, P.D., 2011. Quaternary Glaciations - Extent and Chronology: A Closer Look. Elsevier.

Feruglio, V., Leroy-Prost, C., 2001. Fiche objets arciformes (en forme d'oméga). In: Ramseyer, D. (Ed.), Fiches Typologiques de l'industrie de l'os Préhistorique. Société Préhistorique Française, Paris, pp. 17-21. 
Fortea Pérez, J., Rasilla, de la, M., Rodríguez Otero, V., 1995. La cueva de Llonín (Llonín, Peñamellera Alta): campañas de 1991 a 1994. Excavaciones Arqueológicas en Asturias 33-43.

Fourloubey, Ch., 1996. La production de raclettes au Chatenet (Saint-Front de Pradoux, Dordogne). Paleo 8, 269-275.

Fourloubey, Ch., 1998. Badegoulien et premiers temps du Magdalénien. Un essai de clarification à l'aide d'un exemple : la vallée de l'Isle en Périgord. Paleo 10, 185-209.

Gaussen, J., 1980. Le Paléolithique supérieur de plein air en Périgord. Secteur Mussidan-Saint-Astier, moyenne vallée de 1'Isle, Gall. Préhist., supplément n ${ }^{\circ} 14$, CNRS, Paris.

Gaussen, J., Moissat, J.-C., 1990. Le Chatenet à Saint-Front-De-Pradoux (Dordogne) station magdalénienne à raclette. Gall. Préhist. 32, 29-63.

Gellibert, B., Merlet, J.-C., 2001. Le gisement badegoulien de Cabannes (commune de Brocas-les-Forges, Landes). Archéol. des Pyr. Occid. et des Landes 20, 81-104.

Geneste, J.-M., 1991. Systèmes techniques de production lithique : variations techno-économiques dans les processus de réalisation des outillages paléolithiques. Tech. et Cult. 17-18, 1-36.

Inizan, M.-L., Reduron-Ballinger, M., Roche, H., Tixier, J., 1995. Technologie de la pierre taillée. Préhistoire de la pierre taillée 4, CREP, Meudon.

Jaubert, J., 2013. Le Quercy pléistocène : région à peuplement continu depuis 0,3 Ma ? Archéo-stratigraphies et datations radiométriques. In: Jarry M., Brugal J.-Ph., Ferrier C. (Eds.), Modalités d'occupation et exploitation des milieux au Paléolithique dans le Sud-Ouest de la France : l'exemple du Quercy, actes de la session C67 du XVème Congrès de 1'UISPP, septembre 2006, Lisbonne, Paleo, supplément $\mathrm{n}^{\circ} 4$, Les Eyzies-de-Tayac, pp. 67-106.

Klaric, L., 2003. L'unité technique des industries à burins du Raysse dans leur contexte diachronique. Réflexions sur la variabilité culturelle au Gravettien à partir des exemples de la Picardie, d'Arcy-sur-Cure, de Brassempouy et du Cirque de la Patrie. University of Paris 1-Panthéon Sorbonne, unpublished PhD dissertation.

Lafarge, A., 2014. Entre plaine et montagne: techniques et cultures du Badegoulien du Massif central, de l'Allier au Velay. University of Montpellier III, unpublished PhD dissertation.

Langlais, M., Pétillon, J.-M., Archambault de Beaune, S., Cattelain, P., Chauvière, F.-X., Letourneux, C., Szmidt, C., Bellier, C., Beukens, R., David, F., 2010. Une occupation de la fin du Dernier Maximum glaciaire dans les Pyrénées: le Magdalénien inférieur de la grotte des Scilles (Lespugue, HauteGaronne). Bull. Soc. Préhist. Fr. 107, 5-51. doi:10.3406/bspf.2010.13909

Langlais, M., Ducasse, S., Sitzia, L., Constans, G., Chalard, P., Faivre, J.-Ph., Lacrampe-Cuyaubère, F., Muth, X., 2016. Le site de plein air de Mirande 2 (Vaïssac, Tarn-et-Garonne) : un nouveau jalon badegoulien en Bas-Quercy. Paleo 27, 207-233.

Langley, M.C., Pétillon, J.-M., Christensen, M., 2016. Diversity and Evolution of Osseous Hunting Equipment During the Magdalenian (21,000-14,000 cal BP). In: Langley, M.C. (Ed.), Osseous Projectile Weaponry: Towards an Understanding of Pleistocene Cultural Variability, Vertebrate Paleobiology and Paleoanthropology. Springer Netherlands, Dordrecht, pp. 143-159. doi:10.1007/978-94-024-0899-7_10

Le Guillou, Y., 2012. Premiers regards sur la matière dure animale ouvragée. In: Clottes J., Giraud J.-P. et Chalard P. (Eds.), Solutréen et Badegoulien au Cuzoul de Vers. Des chasseurs de rennes en Quercy, ERAUL 131, Liège, pp. 379-354.

Le Tensorer, J.-M., 1981. Le Paléolithique de l'Agenais, Cahiers du quaternaire, CNRS, Paris.

Le Tensorer, J.-M., 1996. La question magdalénienne: Magdalénien ancien ou Badegoulien ? Eléments de réponse à partir d'exemples en Aquitaine et en Suisse. Tübinger Monographien zur Urgeschichte 11, 297-307.

Leesch, D., Müller, W., Nielsen, E., Bullinger, J., 2012. The Magdalenian in Switzerland: Re-colonization of a newly accessible landscape. Quat. Int. 272-273, 191-208.

Lenoir, M., 1976. Etude technique et typologique des "pièces à retouches anormales" de la station de la Bertonne, commune de Peujard, Gironde. Bull. Soc. Préhist. Fr. 73, 43-47.

Lenoir, M., 1987. La pièce de la Bertonne, “fossile directeur” du Magdalénien ancien ? Bull. Soc. Préhist. Fr. 84, 167-171.

Malgarini, R., Mevel, L., Bereiziat, G., Bodu, P., Cupillard, C., Debout, G., Nicolas, C., 2017. Les faciès du Magdalénien moyen dans l'est de la France: confrontation et discussion des industries osseuses et lithiques. In: Bourdier, C., Chehmana, L., Malgarini, R., Połtowicz-Bobak, M. (Eds.), L'essor du Magdalénien. Aspects culturels, symboliques et techniques des facies à Navettes et à Lussac-Angles, actes de la séance de la Société préhistorique française de Besançon, 17-19 octobre 2013, Séances de la Soc. Préhist. Fr. 8, Société préhistorique française, Paris, pp. 135-152. doi:10.2016

MARGO Project members, 2009. Constraints on the magnitude and patterns of ocean cooling at the Last Glacial Maximum. Nature Geoscience 2, 127-132. doi:10.1038/ngeo411 
Mix, A.C., Bard, E., Schneider, R., 2001. Environmental processes of the ice age: land, oceans, glaciers (EPILOG). Quat. Sci. Rev. 20, 627-657. doi:10.1016/S0277-3791(00)00145-1

Monin, G., 2014. Site badegoulien "le Péhau”, Coimères, Gironde, rapport final d'opération, Paléotime, Service Régional de l'Archéologie d'Aquitaine, Bordeaux.

Montoya, C., Averbouh, A., Bignon-Lau, O., Dumarçay, G., Goutas, N., Pasquini, A., Peschaux, C., Rassat, S., 2019. Le "Colombier" à Chézy-sur-Marne (Aisne, France) : analyses préliminaires d'un site inédit du Dernier Maximum Glaciaire. In: Montoya C., Fagnard J.-P., Locht J.-L. (Eds.), Préhistoire de l'Europe du Nord-Ouest: mobilité, climats et entités culturelles, actes du 28ème Congrès Préhistorique de France, Session n², Palethnologie du Paléolithique supérieur ancien: où en sommes-nous ? Amiens, 30 mai-4 juin 2016, Société préhistorique française, Paris, pp. 141-163.

Morala, A., 1993. Technologie lithique du Magdalénien ancien de l'abri Casserole (Les Eyzies de Tayac, Dordogne). Paleo 5, 193-208.

Neugebauer-Maresch, Ch., Einwögerer, Th., Richter, J., Maier, A., Hussain, S.T., 2016. Kammern-Grubgraben. Neue Erkenntnisse zu den Grabungen 1985-1994. Archaeologia Austriaca 100, 225-254.

Oberlin, Ch., Valladas, H., 2012. Datations par la méthode du carbone 14 des niveaux solutréens et badegouliens de l'abri sous roche du Cuzoul. In: Clottes J., Giraud J.-P. et Chalard P. (Eds.), Solutréen et Badegoulien au Cuzoul de Vers. Des chasseurs de rennes en Quercy, ERAUL 131, Liège, pp. 79-84.

O’Brien, M.J., Boulanger, M.T., Collard, M., Buchanan, B., Tarle, L., Straus, L.G., Eren, M.I., 2014. On thin ice: problems with Stanford and Bradley's proposed Solutrean colonisation of North America. Antiquity 88, 606-613. doi:10.1017/S0003598X0010122X

Ortega, I., Fourloubey, Ch., Bertran, P., Grigoletto, F., Beugnier, V., 2005. Les Sablons (Marsas, Gironde), Fieldwork report, Bordeaux, INRAP.

Pasquini, A., Monin, G., Fernandes, P., 2014. Integrated functional studies of Badegoulian lithic industry. Preliminary results of Le Péhau (Coimères, France). In: Marreiros, J., Bicho, N., Gibaja, J.F. (Eds.), International Conference on Use-Wear Analysis, Cambridge Scholars Publishing, Newcastle, pp. 321330 .

Pelegrin, J., 1995. Technologie lithique : une méthode appliquée à l'étude de deux séries du Périgordien ancien, Cahiers du quaternaire 20, CNRS, Paris.

Pelegrin, J., 2000. Les techniques de débitage laminaire au Tardiglaciaire: critères de diagnose et quelques réflexions. In: Valentin, B., Bodu, P., Christensen, M. (Eds.), L'Europe centrale et septentrionale au Tardiglaciaire, Mémoires du Musée de Préhistoire d'Ile de France, APRAIF, Nemours, pp. 73-86, 3 fig.

Perlès, C., 1982. Les “outils d'Orville” : des nucléus à lamelles. Studia Praehistorica Belgica 2, 129-148.

Peschaux, C., 2017. La parure des sociétés du Dernier Maximum Glaciaire : évolution des pratiques et traditions ornementales entre la fin du Solutréen, le Badegoulien et le début du Magdalénien dans les Bassins parisien, ligérien et aquitaine. University of Paris 1-Panthéon Sorbonne, unpublished PhD dissertation.

Pétillon, J.-M., 2006. Note méthodologique sur l'étude de l'industrie osseuse: la recherche systématique de raccords. Bull. Soc. Préhist. Fr. 103, 175-179.

Pétillon, J.-M., Averbouh, A., 2012. Le travail du bois de renne dans les couches badegouliennes. In: Clottes J., Giraud J.-P. et Chalard P. (Eds.), Solutréen et Badegoulien au Cuzoul de Vers. Des chasseurs de rennes en Quercy, ERAUL 131, Liège, pp. 359-386.

Pétillon, J.-M., Chauvière, F.-X., 2017. The Badegoulian bone and antler toolkit: current state of knowledge. Presented at the 12th Meeting of the Worked Bone Research Group, International Council for Archaeozoology, Granada, Spain, 23-27 May 2017.

Pétillon, J.-M., Ducasse, S., 2012. From flakes to grooves: A technical shift in antlerworking during the last glacial maximum in southwest France. J. Hum. Evol. 62, 435-465. doi:10.1016/j.jhevol.2011.12.005

Primault, J., Brou, L., Bouché, F., Catteau, C., Gaussein, P., Gioé, A., Griggo, C., Houmard, C., Le Fillâtre, V., Peschaux, C., 2020. L'émergence du Magdalénien : rythme des changements techniques au cours du 18e millénaire BP au Taillis des Coteaux (Antigny, Vienne, France). In: Straus L.G., Langlais M. (Eds.), Magdalenian Chronostratigraphic Correlations and Cultural Connections between Cantabrian Spain and Southwest France... and beyond, actes de la Séance de La Société préhistorique Française, Séances de la Soc. Préhist. Fr. 15, Paris 2018. Société préhistorique française, Paris, pp. 205-231.

Rasilla Vives, M. de la, Duarte Matías, E., Aura Tortosa, J.E., Sanchis Serra, A., Carrión Marco, Y., Pérez Ripoll, M., Rodríguez Otero, V., 2019. The Llonin Cave (Peñamellera Alta, Asturias, Spain), level III (Galería): techno-typological characterisation of the Badegoulian lithic and bone assemblages. In: Costamagno, S., Deschamps, M., Milcent, P.-Y., Pétillon, J.-M., Renard, C., Valdeyron, N. (Eds.), La conquête de la montagne: des premières occupations humaines à l'anthropisation du milieu, actes du $142^{\text {ème }}$ Congrès du CTHS, Éditions du Comité des travaux historiques et scientifiques, Paris. https://books.openedition.org/cths/6362

Rasmussen, S.O., Bigler, M., Blockley, S.P., Blunier, T., Buchardt, S.L., Clausen, H.B., Cvijanovic, I., DahlJensen, D., Johnsen, S.J., Fischer, H., Gkinis, V., Guillevic, M., Hoek, W.Z., Lowe, J.J., Pedro, J.B., 
Popp, T., Seierstad, I.K., Steffensen, J.P., Svensson, A.M., Vallelonga, P., Vinther, B.M., Walker, M.J.C., Wheatley, J.J., Winstrup, M., 2014. A stratigraphic framework for abrupt climatic changes during the Last Glacial period based on three synchronized Greenland ice-core records: refining and extending the INTIMATE event stratigraphy. Quat. Sci. Rev. 106, 14-28. doi:10.1016/j.quascirev.2014.09.007

Raynal, J.-P., Lafarge, A., Rémy, D., Delvigne, V., Guadelli, J.-L., Costamagno, S., Le Gall, O., Daujeard, C., Vivent, D., Fernandes, P., Le Corre-Le Beux, M., Vernet, G., Bazile, F., Lefèvre, D., 2014. Datations SMA et nouveaux regards sur l'archéo-séquence du Rond-du-Barry (Polignac, Haute-Loire). Comptes Rendus Palevol 13, 623-636. https://doi.org/10.1016/j.crpv.2014.03.010

Reade, H., Tripp, J.A., Charlton, S., Grimm, S., Sayle, K.L., Fensome, A., Higham, T.F.G., Barnes, I., Stevens, R.E., 2020. Radiocarbon chronology and environmental context of Last Glacial Maximum human occupation in Switzerland. Sci. Rep. 10, 1-11. doi:10.1038/s41598-020-61448-7

Reimer, P.J., Austin, W.E.N., Bard, E., Bayliss, A., Blackwell, P.G., Bronk Ramsey, C., Butzin, M., Cheng, H., Edwards, R.L., Friedrich, M., Grootes, P.M., Guilderson, T.P., Hajdas, I., Heaton, T.J., Hogg, A.G., Hughen, K.A., Kromer, B., Manning, S.W., Muscheler, R., Palmer, J.G., Pearson, C., Plicht, J. van der., Reimer, R.W., Richards, D.A., Scott, E.M., Southon, J.R., Turney, C.S.M., Wacker, L., Adolphi, F., Büntgen, U., Capano, M., Fahrni, S.M., Fogtmann-Schulz, A., Friedrich, R., Köhler, P. Kudsk, S., Miyake, F., Olsen, J., Reinig, F., Sakamoto, M., Sookdeo, A., Talamo, S., 2020. IntCal20 Northern Hemisphere Radiocarbon Age Calibration Curves (0-55 cal kBP). Radiocarbon 62, 4:725-757.

Rémy, D., 2013. Caractérisation techno-économique d'industries en bois de cervidés du Badegoulien et du Magdalénien : le cas du Rond-du-Barry (Haute-Loire) et de Rochereil (Dordogne), University of Montpellier 3, unpublished $\mathrm{PhD}$ dissertation.

Renard, C., 2010. Les premières expressions du Solutréen dans le Sud-Ouest français. Evolution technoéconomique des équipements lithiques au cours du Dernier Maximum glaciaire, BAR International Series 2070, Oxford.

Renard, C., Ducasse, S., 2015. De la rupture typologique à la fracture socio-économique. Implications sur les systèmes de mobilité entre Solutréen récent et Badegoulien dans le Sud-Ouest français (24-21 Ka cal. BP). In: Naudinot N., Meignen L., Binder D., Querré G. (Eds.), Les systèmes de mobilité de la Préhistoire au Moyen Âge, actes des XXXVe Rencontres Internationales d'Archéologie et d'Histoire d'Antibes, APDCA, Antibes, pp. 193-208.

Rigaud, A., 2004. Fiche transformation du bois de Renne au Badegoulien. L'exemple de l'abri Fritsch (Indre, France). In: Ramseyer D. (Ed.), Industrie de l'os préhistorique, cahier XI : Matières et Techniques, Société préhistorique française, Paris, pp. 75-78.

Rigaud, J.-Ph., 1989. Le Magdalénien en Europe. La structuration du Magdalénien, actes du colloque de Mayence organisé dans le cadre du XIe Congrès de l'UISPP, 1987, ERAUL 38, Presses Universitaires de Liège, Liège.

Rios Garaizar, J., Maidagán, D.G., Olivencia, A.G., Alonso, D.A., Avilés, E.I., Moreno, A.G., Pimentel, D.G., Calleja, Z.S.P., 2013. El final del Solutrense en el Oriente Cantábrico a través de las ocupaciones de la Cueva de Arlanpe (Lemoa, Vizcaya). Zephyrus 72, 15-38.

Sacchi, D., 1967. Le Paléolithique supérieur dans la Montagne Noire audoise, état des recherches et perspectives. Atacina 1, 12-13.

Sacchi, D., 1969. Observations sur la stratigraphie de la Petite Grotte de Bize (Aude). Atacina 4, 3-25.

Sacchi, D., 1986. Le Paléolithique supérieur du Languedoc occidental et du Roussillon, Gall. Préhist., supplément $\mathrm{n}^{\mathrm{0}} 21, \mathrm{CNRS}$, Paris.

Sacchi, D., 2003. Retour sur la station badegoulienne de Lassac (Aude). Bull. Soc. Préhist. Ariège-Pyrénées 58, $157-162$.

Sedlmeier, J., 2010. Die jungpaläolithischen Funde aus der Mittleren Fundschicht der Kastelhöhle Nord im nordwestschweizerischen Kaltbrunnental, Himmelried SO. Ein Nachweis für die Begehung der Schweiz durch Mensch und Tier kurz nach dem Kältemaximum der letzten Eiszeit. Jahrbuch der Archäologie Schweiz 7-43.

Séronie-Vivien, M.-R., 1995. La grotte de Pégourié, Caniac-du-Causse, Lot : Périgordien, Badegoulien, Azilien, Age du Bronze, Préhistoire Quercinoise, supplément nº 2, Cressensac.

Sireix, M., 1988. Un site magdalénien ancien : le Pourquey à Castelviel. In: L'Entre-Deux-Mers à la recherche de son identité, actes du premier colloque de l'Association Historique des Pays de Branne, Branne, 1920 Septembre 1987, CLEM-AHB, pp. 13-18.

Škrdla, P., Nejman, L., Bartík, J., Rychtař́ková, T., Nikolajev, P., Eigner, J., Nývltová Fišáková, M., Novák, J., Polanská, M., 2016. Mohelno - A terminal Last Glacial Maximum industry with microlithic tools made on carenoidal blanks. Quat. Int. 406, 184-194. doi:10.1016/j.quaint.2015.05.055

Sonneville-Bordes, D. de, 1966. L'évolution du Paléolithique supérieur en Europe occidentale et sa signification. Bull. Soc. Préhist. Fr. 63, 3-34. doi:10.3406/bspf.1966.4061 
Soriano, S., Lechenet, H., 2000. Des «Orvilles » en Bourgogne. L’occupation du site de la Roncière (Bèze, Côte-d'Or) au Paléolithique supérieur. In: Pion G. (Ed.), Le Paléolithique supérieur récent : nouvelles données sur le peuplement et l'environnement, actes de la Table ronde de Chambéry, 12-13 mars 1999, Mémoire de la Soc. Préhist. Fr. 28, Société préhistorique française, Paris, pp. 223-233.

Stanford, D., Bradley, B., 2002. Ocean trails and prairie paths? Thoughts about Clovis origins. In: Jablonski, N.G. (Ed.), The First Americans: The Pleistocene Colonization of the New World, Memoirs of the California Academy of Sciences. California Academy of Sciences, San Francisco, pp. 255-271.

Straus, L.G., 2018. The Upper Paleolithic of Iberia. Trabajos de prehistoria 75, 9-51.

Straus, L.-G., Clark, G.-A., 2000. La grotte de la Riera (Asturies) et la question du Solutréen Cantabrique (et Ibérique). Bull. Soc. Préhist. Fr. 97, 129-132.

Straus, L.-G., Langlais, M. (Eds.), 2020. Magdalenian Chronostratigraphic Correlations and Cultural Connections between Cantabrian Spain and Southwest France... and beyond, actes de la Séance de La Société préhistorique Française, Séances de la Soc. Préhist. Fr. 15, Paris 2018. Société préhistorique française, Paris.

Street, M., Terberger, Th., 1999. The last Pleniglacial and the human settlement of Central Europe : new information from the Rhineland site of Wiesbaden-Igstadt. Antiquity 73, 259-272.

Terberger, T., 2013. Le Dernier Maximum glaciaire entre le Rhin et le Danube, un réexamen critique. In: Bodu P., Chehman L., Klaric L., Mevel L., Soriano S., Teyssandier N. (Eds.), Le Paléolithique supérieur ancien de l'Europe du Nord-Ouest, actes du colloque de Sens, 15-18 avril 2009, Mémoire de la Soc. Préhist. Fr. 56, Société préhistorique française, Paris, pp. 415-443.

Tixier, J., 2012. A Method for the study of Stone Tools, ArchéoLogiques 4, Centre National de Recherche Archéologique du Luxembourg, Luxembourg.

Trotignon, F., Poulain, Th., Leroi-Gourhan, Arl., 1984. Études sur l'abri Fritsch (Indre), Gall. Préhist., supplément $n^{\circ} 19$, CNRS, Paris.

Utrilla, P., 1986. La varilla "pseudoexcisa" de Aitbitarte IV y sus paralelos franceses. In: Estudios En Homenaje al Dr. Antonio Beltran Martinez, Universidad de Zaragoza, pp. 205-225.

Utrilla, P., 1989. El Magdaleniense inferior en la Costa Cantabrica, In: Rigaud J.-P. (Ed.), Le Magdalénien en Europe. La structuration du Magdalénien, actes du colloque de Mayence organisé dans le cadre du XIe Congrès de 1'UISPP, 1987, ERAUL 38, pp. pp. 399-418.

Utrilla Miranda, P., Rodanés Vicente, J.M., Blasco Sancho, M.F., 2020. El Magdaleniense arcaico en España. Algunas reflexiones para el debate. In: Straus L.G., Langlais M. (Eds.), Magdalenian Chronostratigraphic Correlations and Cultural Connections between Cantabrian Spain and Southwest France... and beyond, actes de la Séance de La Société préhistorique Française, Séances de la Soc. Préhist. Fr. 15, Paris 2018. Société préhistorique française, Paris, pp. 13-39.

Valentin, B., 2008. Jalons pour une paléohistoire des derniers chasseurs (XIVe-VIe millénaire avant J.-C.), Cahiers archéologiques de Paris 1, Publications de la Sorbonne, Paris.

Villa, P., 1982. Conjoinable Pieces and Site Formation Processes. American Antiquity 47, $276-290$. doi:10.2307/279901

Zickel, M., Becker, D., Verheul, J., Yasa Yener, Willmes, C., 2016. Paleocoastlines GIS dataset. doi:10.5880/SFB806.20

Zilhão, J., 2013. Forty years after Roche 64: a far-west view of the Solutrean. In: SERAP (Ed.), Le Solutréen... 40 ans après Smith' 66, actes du colloque de Preuilly-Sur-Claise, 21 Octobre-01 Novembre 2007, Revue archéologique du Centre de La France, supplément 47, Fédération pour l'édition de la Revue archéologique du Centre de la France, Tours, pp. 87-99.

\section{Captions}

Figure 1. A: Location of the main Badegoulian sites, together with the Badegoulian, Badegoulian-like, Upper Solutrean and Salpetrian sites mentioned in the text (written in full; white circles, lozenges and triangles: caves and rockshelters; black ones: open-air sites; CdV: Cuzoul de Vers; FdD: Fourneau-du-Diable; LH: Laugerie-Haute; PCB: Petit Cloup Barrat; RdB: Rond-du-Barry; TdC: Taillis-des-Coteaux); \#1: La Chapelle Saint-Mesmin; \#2: Trocadero; \#3: Le Poron des Cuèches; \#4: La Pyramide; \#5: Le Silo; \#6: La Pluche and SaintFiacre; \#7: La Malignière; \#8: La Faye-Godet; \#9: André Ragout rockshelter; \#10: ChezFiacre; \#11: La Bertonne, Croûte Charlus and Mauran 1; \#12: Les Sablons; \#13: Le Gouillard; \#14: Houleau rockshelter and Casevert; \#15: La Pibole and Pellegrue; \#16: Bordeneuve; \#17: Solvieux; \#18: La Croix-de-Fer; \#19: Guillassou and La Station du Burin; \#20: Chancelade; 
\#21: Badegoule; \#22: Les Jamblancs; \#23: Les Braugnes; \#24: La Roche à Tavernat; \#25: Camparnaud and La Rouquette; \#26: La Rivière; \#27: L'église-nord; \#28: Le Réservoir; B: Details of the confidence level assigned to each studied assemblage (see table 1 and material and methods section); C: Chronocultural attribution and indication of preserved osseous equipment within each studied assemblage. CAD S. Ducasse; background map IGN 2012Open Source; LGM coastlines and glacier extents from Ehlers et al., 2011 and Zickel et al., 2016.

Figure 2. The Badegoulian radiometric framework based on a selection of AMS ${ }^{14} \mathrm{C}$ ages from several French key sequences (see Table 2 and section 3 for details about the nature of each dated artifact and the selection criteria). "Badegoulian-like" tagged dates correspond to compatible ages obtained from (or strongly suspected to be) mixed archaeological contexts including a Badegoulian component.

Figure 3. Main Early Badegoulian lithic features from Le Cuzoul de Vers (layers 27 to 22). 14: end-scrapers; 5: composite-tool (end-scraper/burin) made on an imported and massive crested blade with possible intentional breakage (note the transformation of the proximal nonlamellar "notched-burin" into a dihedral burin); 6: semi-abruptly/scaled-retouched large and thin flakes (aka so-called "proto-raclettes": Le Tensorer, 1981; example of dedicated productions linked to this type of tools is notably documented in Casserole NA6 through several refittings: Morala, 1993 and obs. pers.). All the artifacts are from layer 24, except \#2 (layer 22) and \#5 which show inter-layer refitting between layers 24-25-26. Pictures and CAD S. Ducasse, drawing \#2 G. Peyre.

Figure 4. Main Early Badegoulian lithic features from Le Cuzoul de Vers (layers 27 to 22). A: examples of "notched-burins" and related artifacts; note that while \#3 unequivocally corresponds to a flake-edge core, some of the other illustrated artifacts should be interpreted as tools (\#1; extensive techno-functional analysis is needed); B: blade and thin-flakes cores from local alluvial flints. Drawings M. Jarry, pictures S. Ducasse, CAD S. Ducasse and M. Jarry.

Figure 5. The shouldered point-yielding Badegoulian (Le Cuzoul de Vers, layers 21 to 16). A: examples of shouldered points (\#1-8; \#10), associated backed-bladelets (\#8, \#11-14) and thin-blade core; note the refitting \#8 that evidences the combined production of shouldered point and backed-bladelets blanks; B: flake-edge cores (\#1 and 2) and refitted raclettes from shouldered point-yielding assemblages (layers 16 and 20). Drawings S. Ducasse and M. Jarry, pictures S. Ducasse, CAD S. Ducasse and M. Jarry.

Figure 6. Examples of bladelet and microbladelet productions from Late Badegoulian assemblages (A: Mirande 2, Tarn-et-Garonne; B: Lassac locus 1, Aude). Pictures S. Ducasse, drawings S. Ducasse, Célia Fat-Cheung; CAD S. Ducasse.

Figure 7. Main typo-technological features of the Badegoulian bone and antler equipment; A: examples of knapping technique manufacturing wastes (\#1: refitted flake removal sequence from Le Cuzoul de Vers, layer 6; black arrows and numbering indicate the percussion points and their chronological ordering, respectively; \#2: example of desired blank from Le Cuzoul de Vers, layer 12); B: synthetic knapping schéma opératoire consisting in "shaping" the beam of large antlers in order to obtain a cortical "rod" that will then be worked by scraping); C: examples of "domestic" tools and hunting tips (\#1 and 2: long and thin point and self-barbed point from Le Cuzoul de Vers, layers 10 and 10, respectively; \#3 and 4: bone-eyed needle 
from Le Cuzoul de Vers, layers 25 and 11; \#5: antler wedge from Le Cuzoul de Vers, layer 11; \#6: directly dated striated single-beveled point from Pégourié, layer 8c, bearing a "pseudo-excised" decoration; \#7: directly dated recycled striated single-beveled point from Pégourié, layer $8 \mathrm{a}$. Indicated time ranges for each typological group correspond to $2 \sigma$ calibrated ages from directly dated artifacts or associated dated antler technical wastes and/or faunal remains (pictures and schemas: J.-M. Pétillon and J.-F. Peiré, after Pétillon and Averbouh, 2012; Le Guillou, 2012 and Ducasse et al., 2019a).

Figure 8. Challenging the classic Badegoulian chronocultural subdivisions? Comparative evolution of lithic and osseous hunting equipment from 23,5 to 21 cal ka BP in France (Pictures, graphics and drawings S. Ducasse, M. Jarry, J.-M. Pétillon, J.-F. Peiré) and chronostratigraphic correlations with LGM assemblages from Spain (Llonin Cave, level III; radiometric data, drawing and pictures from Rasilla Vives et al., 2019) and Switzerland (Kastelhöhle Nord, layer 4; drawing from Sedlmeier, 2010; radiometric data from Reade et al., 2020). Note that, unlike in figure 7, time ranges were weighted on the basis of archaeostratigraphic successions. US=Upper Solutrean; EB=Early Badegoulian; LM=Lower Magdalenian; CdV: Cuzoul de Vers; Cass ${ }^{\text {rle: }}$ Casserole; Peg: Pégourié; TdC: Taillis-des-Coteaux ; LDDM: Lamelle à dos dextre marginal.

Figure 9. Examples of typical Badegoulian raclettes from the Magdalenian (\#1) and Upper Solutrean (\#2-3) assemblages of Aitzbitarte IV Cave, Basque Country. Pictures and CAD S. Ducasse. 

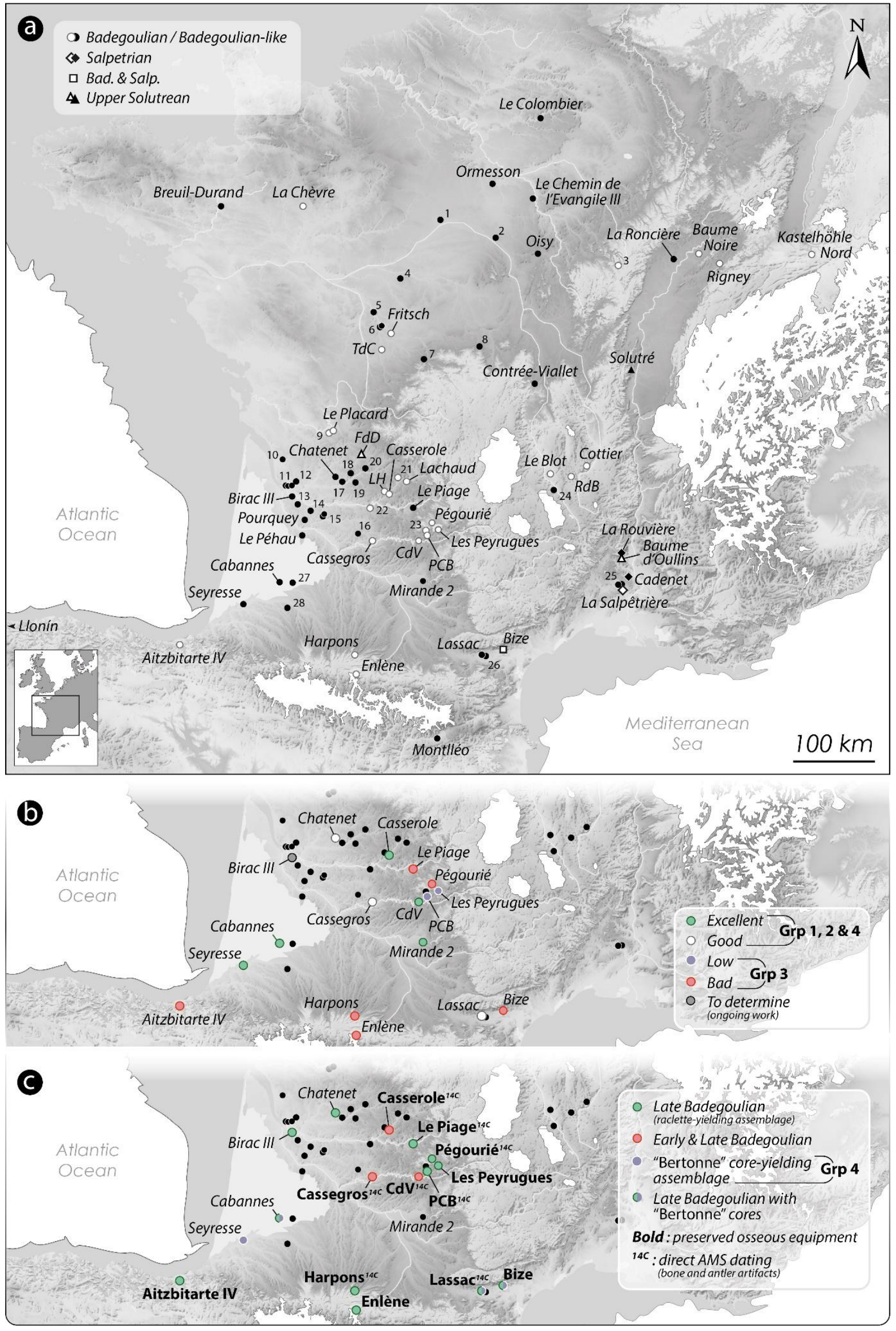


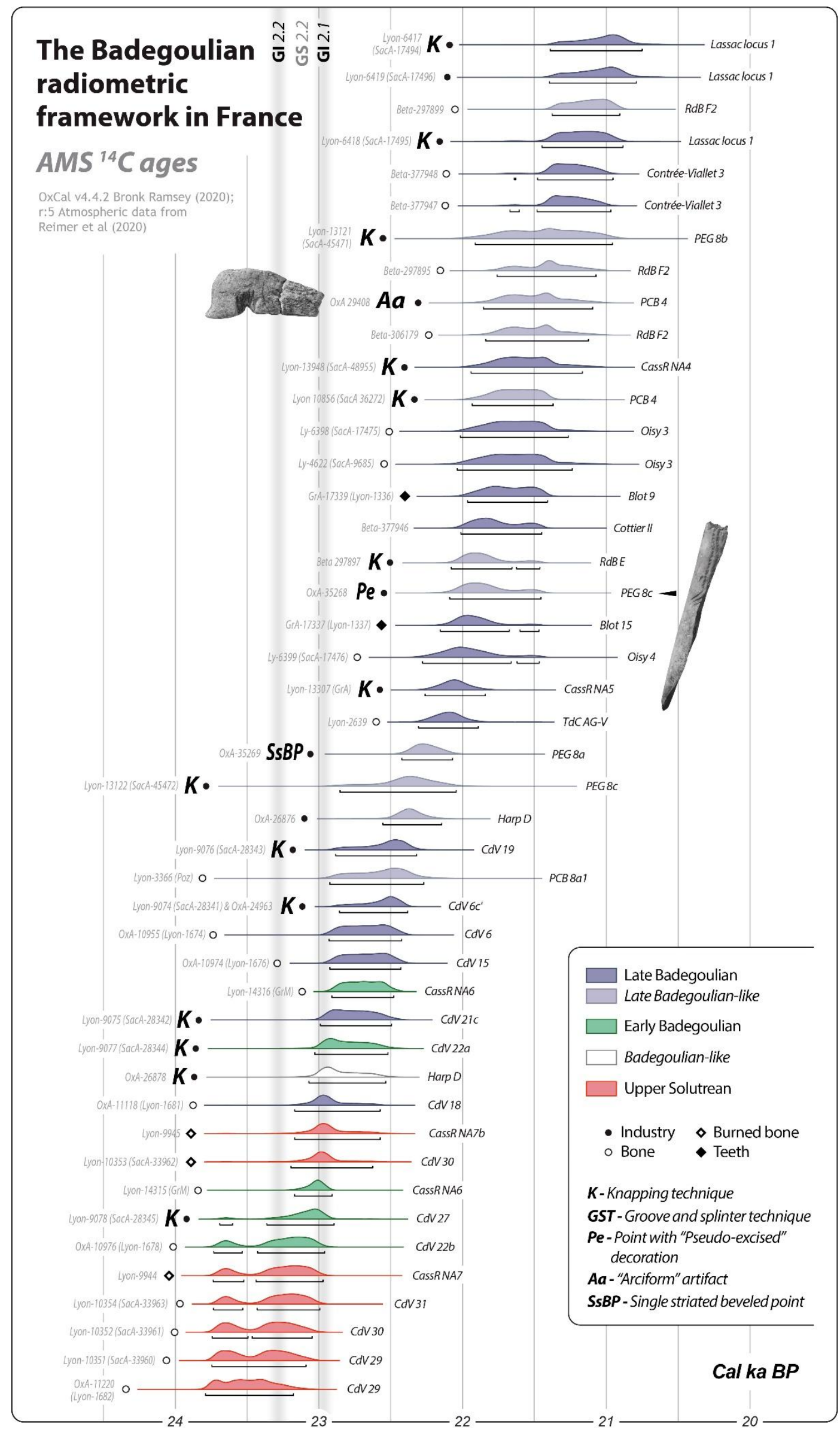




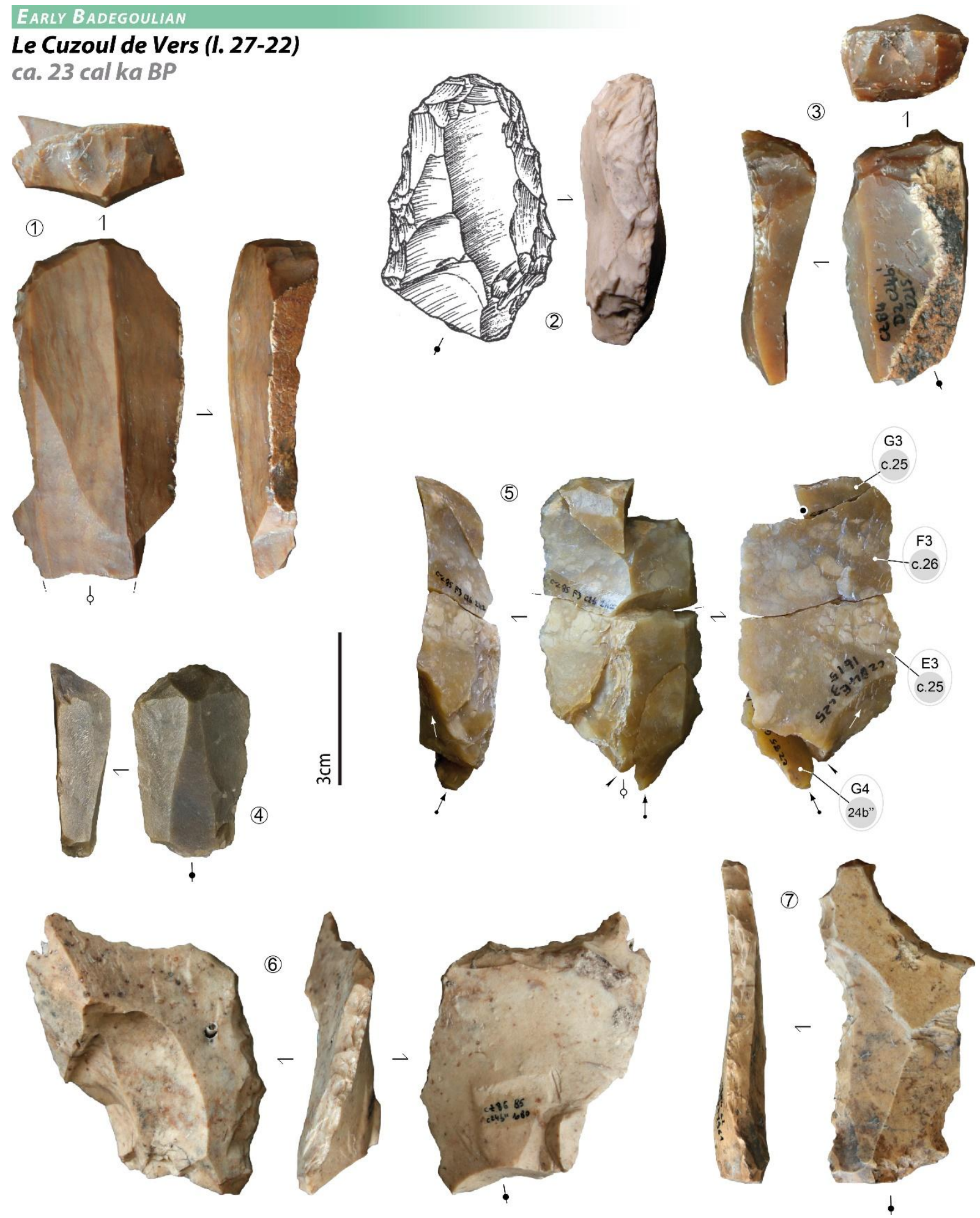



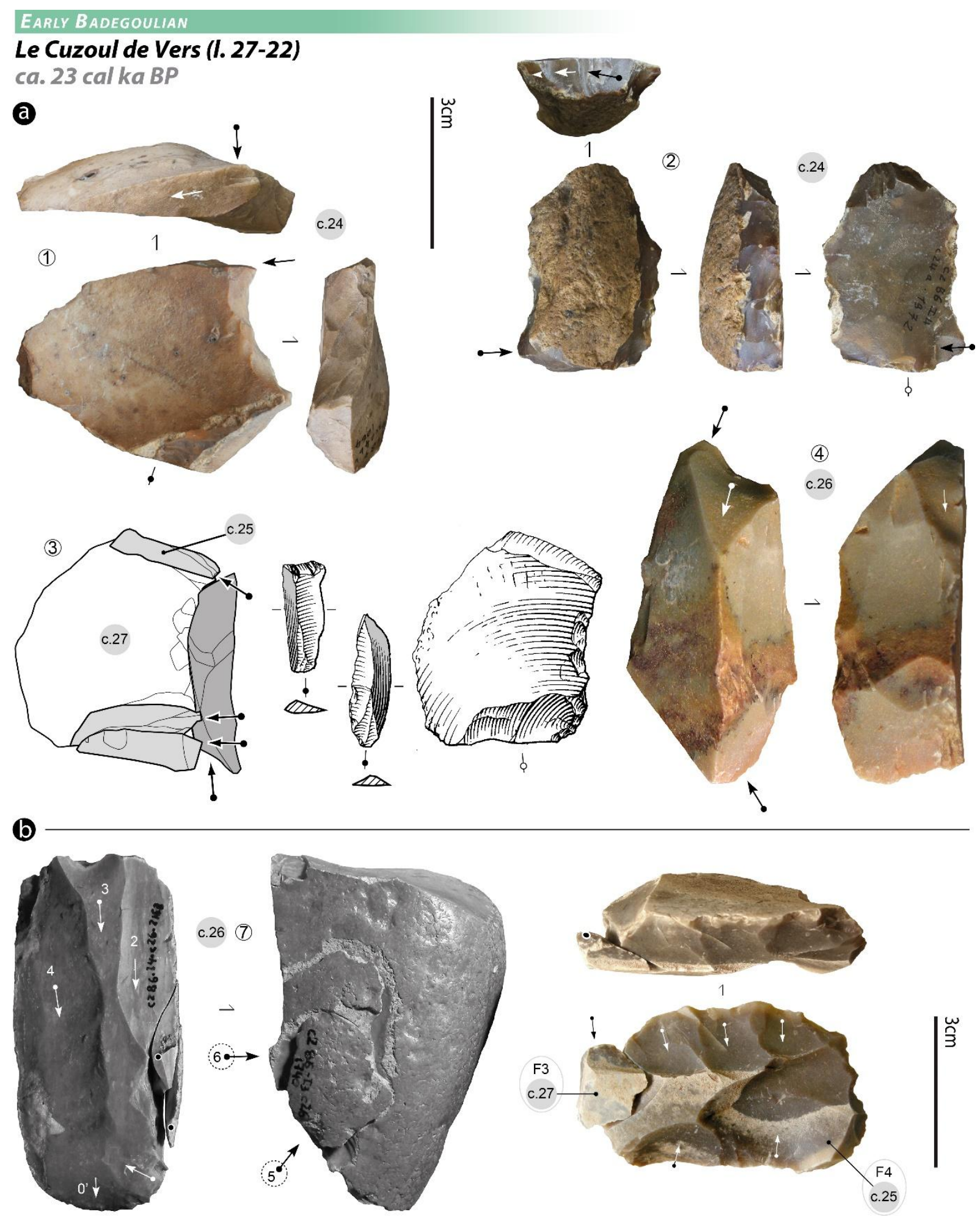
LATE BADEGOULIAN

a Le Cuzoul de Vers (I.21-16)
ca. 23-22.5 cal ka BP

P.
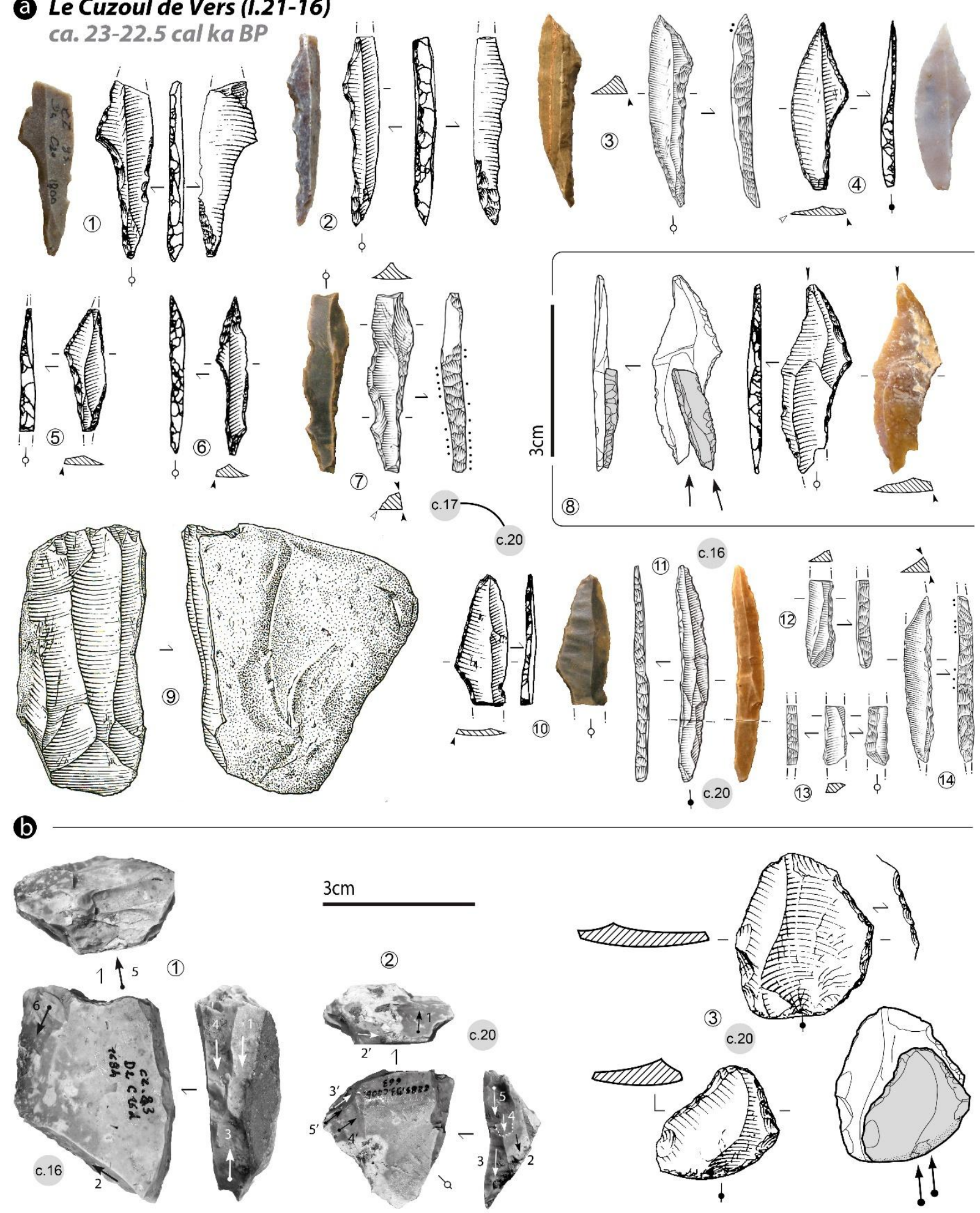
a Mirande 2
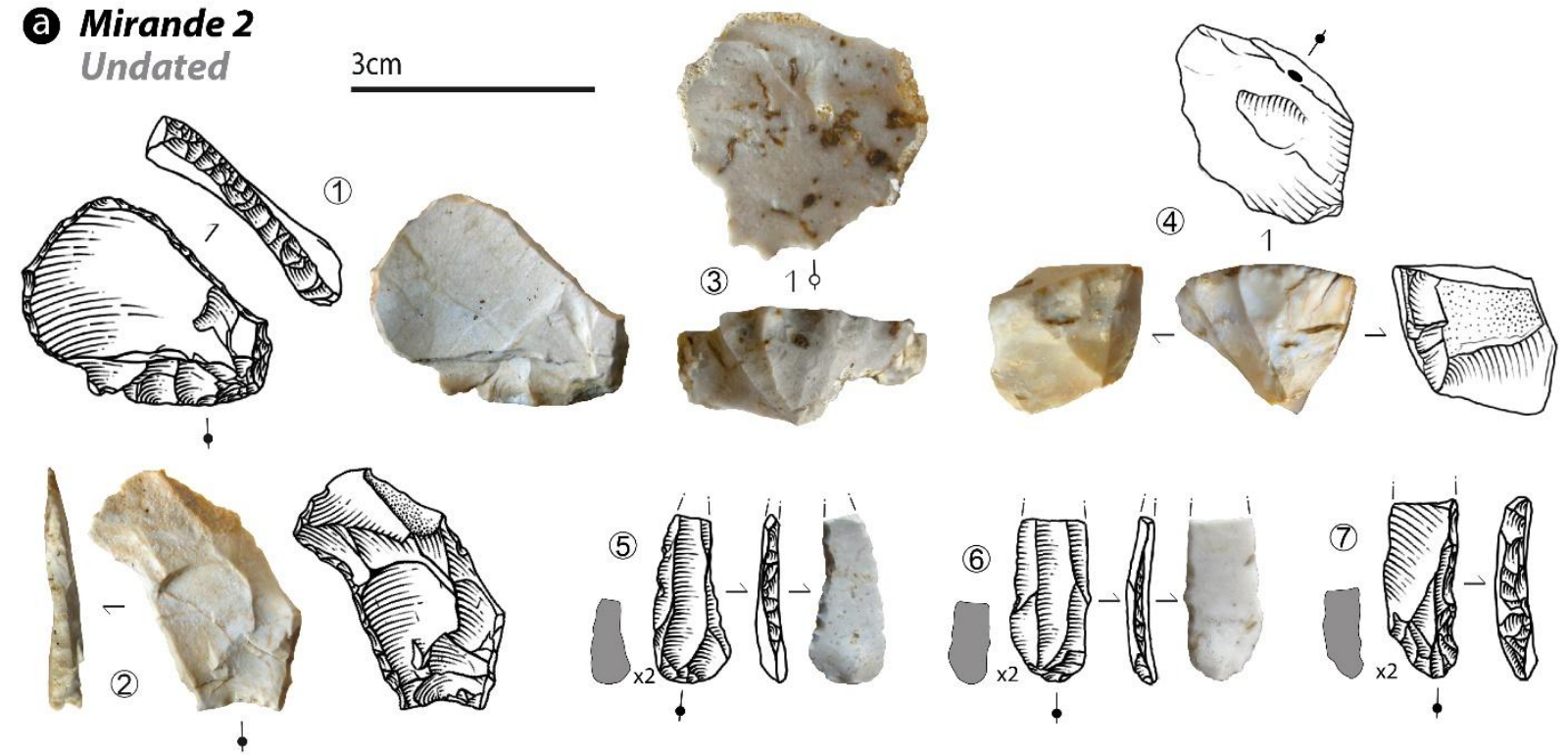

b Lassac, locus 1

21,5-21 cal ka BP

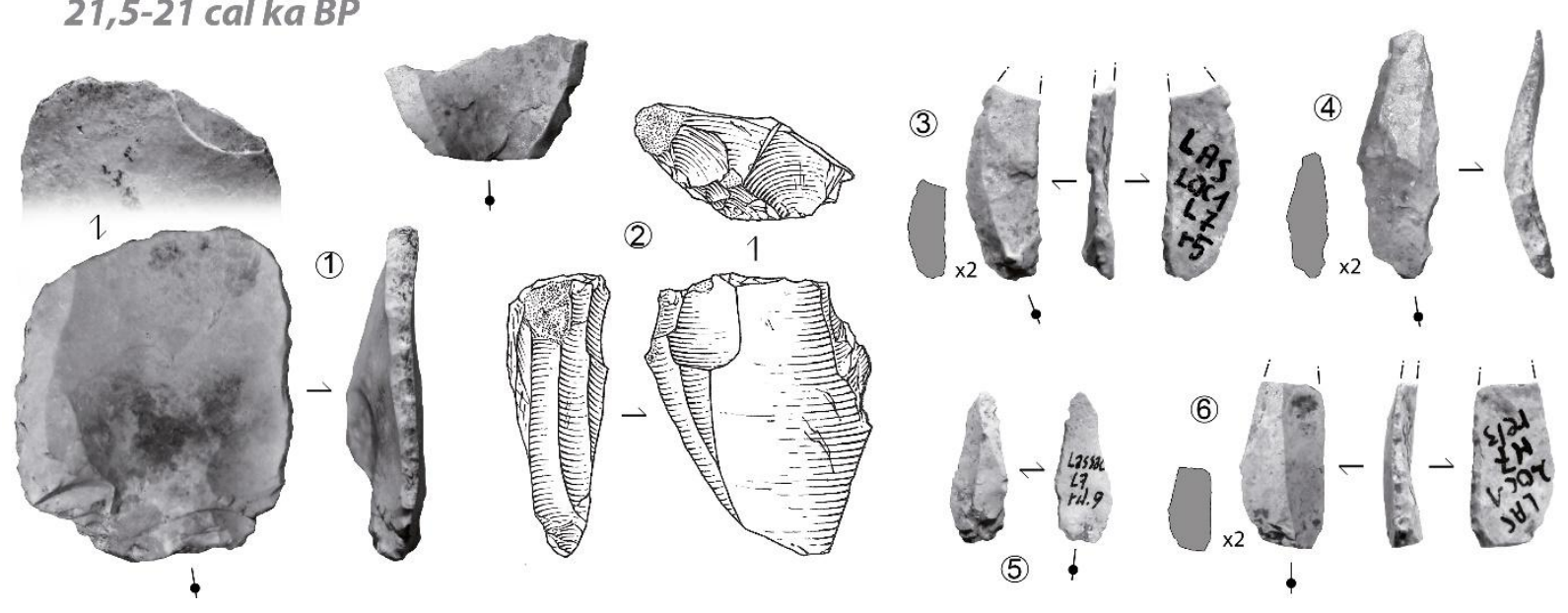




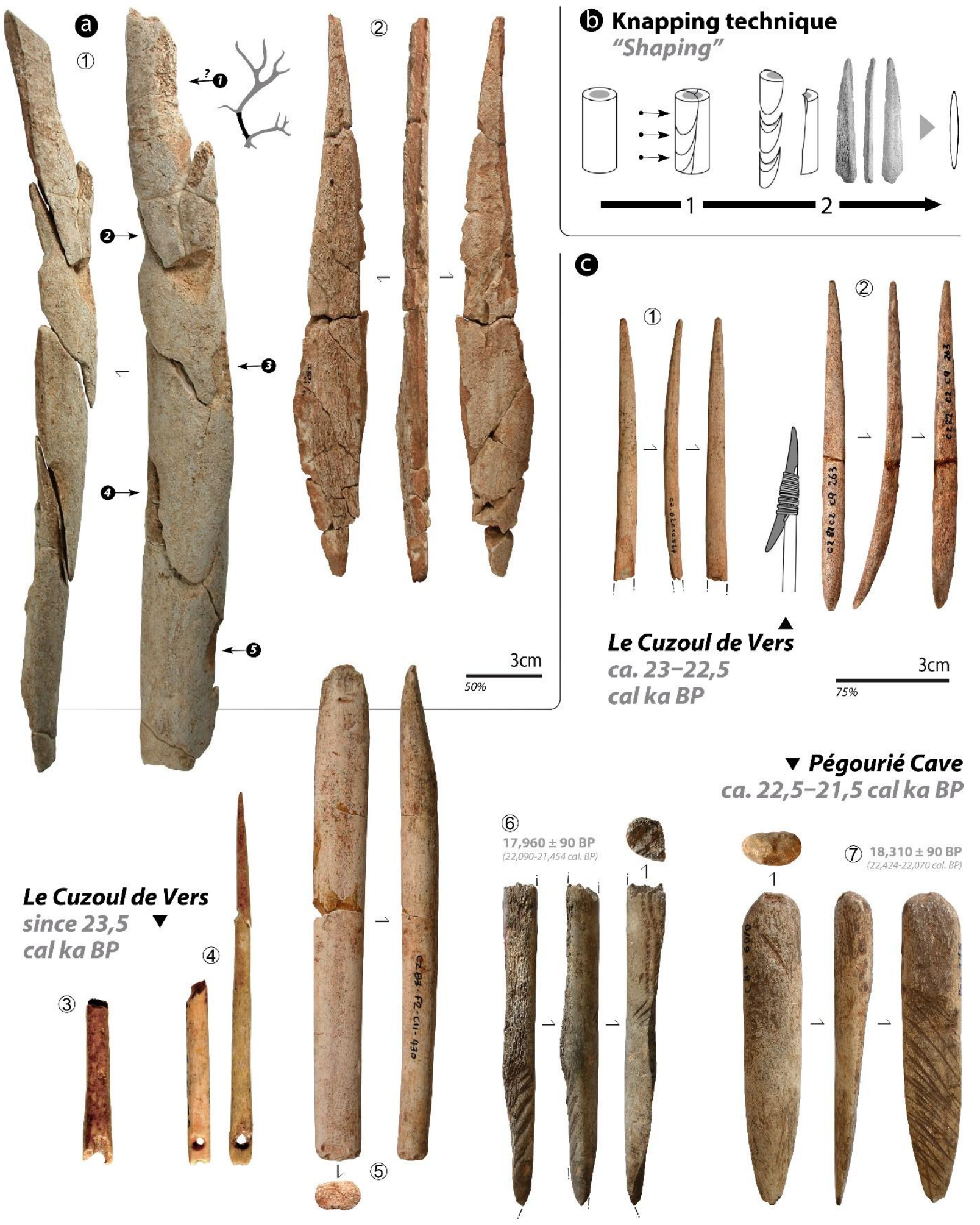




\section{Comparative evolution of the French Badegoulian lithic and osseous hunting equipment}

Combination of archaeostratigraphic and radiometric data (AMS)
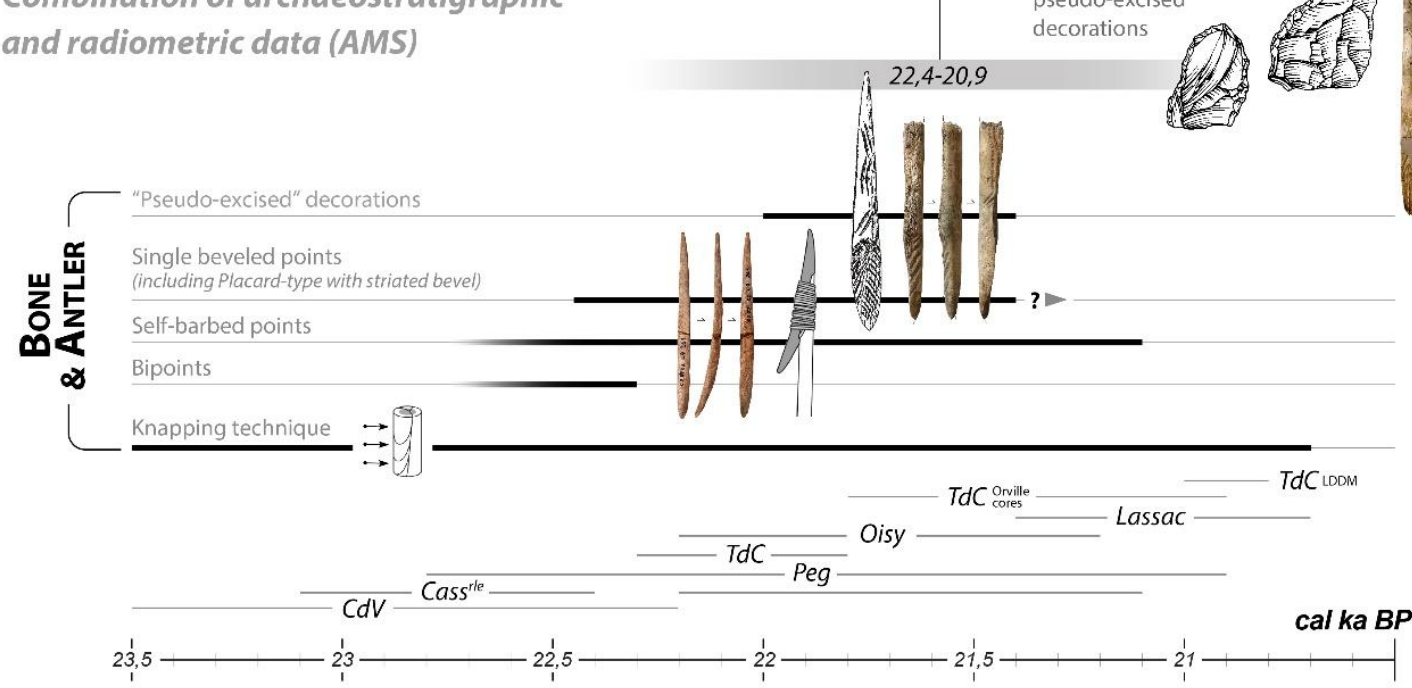

us

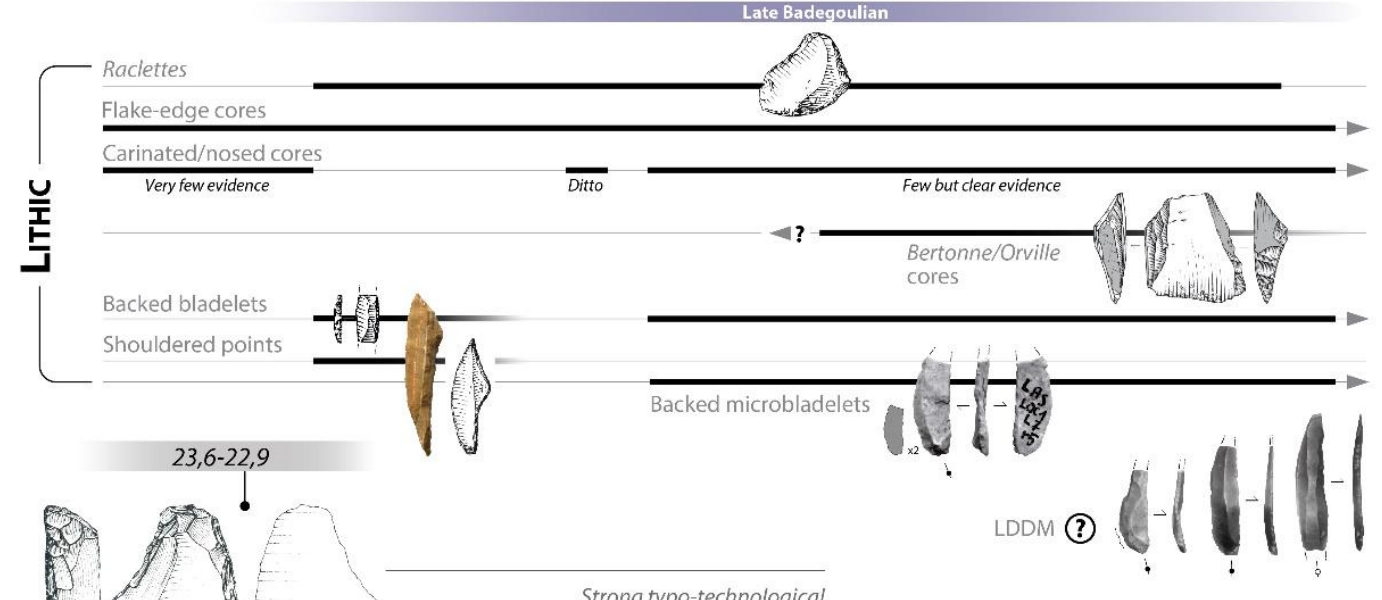

Strong typo-technological

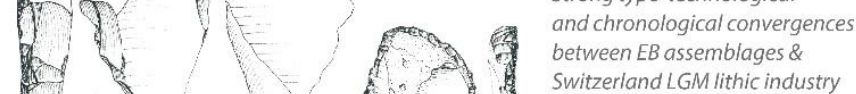

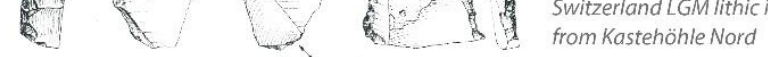




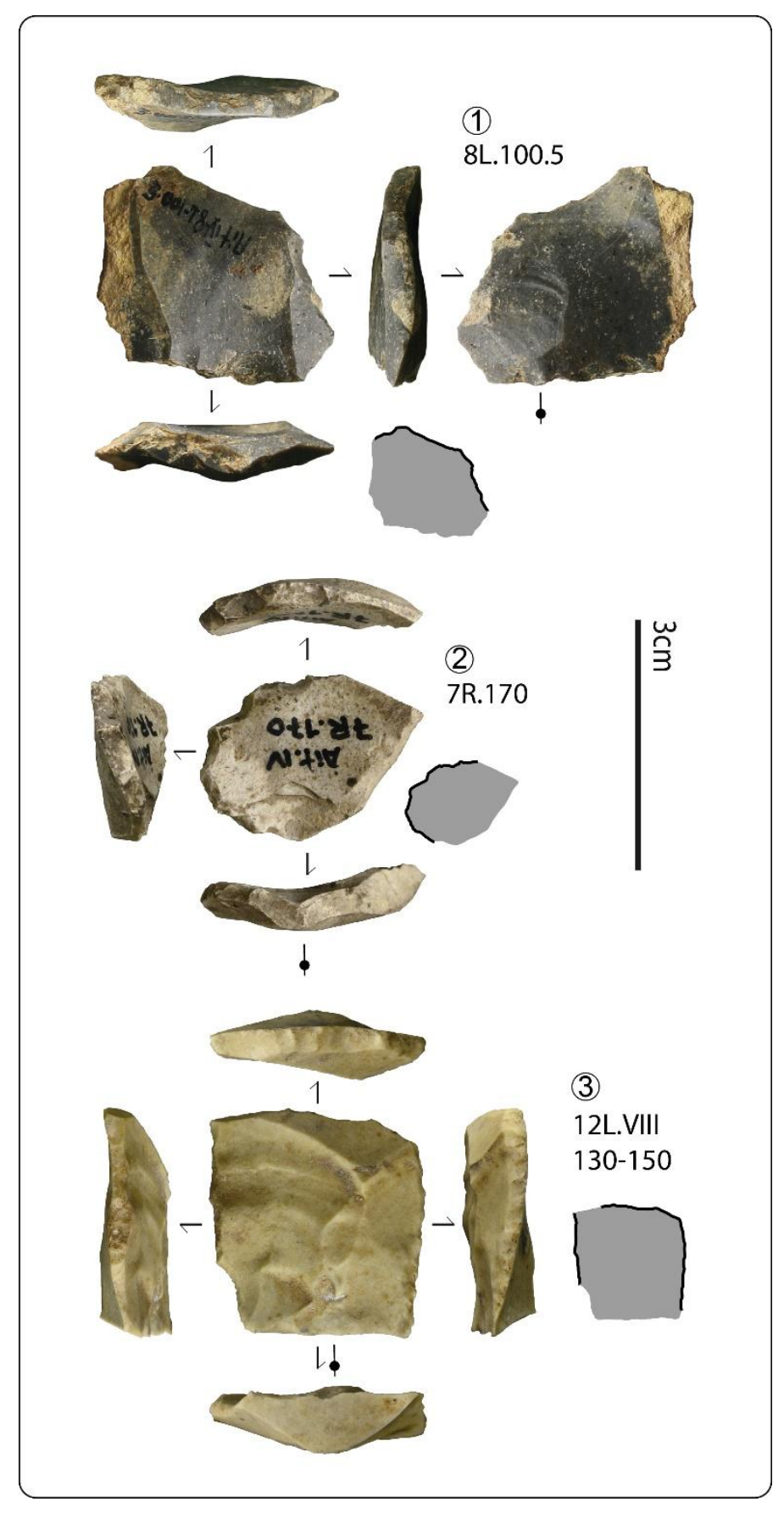




\begin{tabular}{|c|c|c|c|c|c|c|c|c|c|c|}
\hline & Town & Site type & $\begin{array}{l}\text { Years of } \\
\text { excavation }\end{array}$ & Layer/Sector & $\begin{array}{l}\text { Documented } \\
\text { Badegoulian } \\
\text { stages }\end{array}$ & $\begin{array}{l}\text { Bone and } \\
\text { antler } \\
\text { assemblages }\end{array}$ & $\begin{array}{l}\text { AMS } \\
\text { dating* }\end{array}$ & Confidence level & References & Location information \\
\hline \multicolumn{11}{|l|}{ Quercy } \\
\hline $\begin{array}{l}\text { Le Cuzoul } \\
\text { de Vers }\end{array}$ & Vers & Rockshelter & $1982-1986$ & $1-27$ & $E B$ and $L B$ & Y & Yes $(N=19)$ & $\mathrm{E}$ & $\begin{array}{l}\text { Clottes et al., 2012; Ducasse, } \\
2010\end{array}$ & $\begin{array}{r}\text { SRA Occitanie, excavations storage } \\
\text { depot, Toulouse (France) }\end{array}$ \\
\hline Pégourié & $\begin{array}{l}\text { Caniac-du- } \\
\text { Causse }\end{array}$ & Cave & $1967-1988$ & 8 and 9 & LB & Y & Yes $(N=10)$ & $\begin{array}{l}\text { B - intrusive } A z / M / S / G \\
\text { components }\end{array}$ & $\begin{array}{l}\text { Séronie-Vivien dir., 1995; } \\
\text { Ducasse et al., 2019a }\end{array}$ & Pech Merle Museum, Cabrerets (France) \\
\hline $\begin{array}{l}\text { Le Petit } \\
\text { Cloup } \\
\text { Barrat }\end{array}$ & Cabrerets & Cave & 2004-2016 & $\begin{array}{l}8 \mathrm{a} 1 \text { and } \\
\text { evidence } \\
\text { from } 1.4\end{array}$ & LB & Y & Yes $(N=2)$ & $\begin{array}{c}\mathrm{L} \text { - ongoing } \\
\text { archaeostratigraphic } \\
\text { analysis }\end{array}$ & $\begin{array}{l}\text { Castel et al., 2006; Ducasse et } \\
\text { al., } 2011\end{array}$ & Pech Merle Museum, Cabrerets (France) \\
\hline Le Piage & Fajoles & Rockshelter & $\begin{array}{l}1958- \\
1968 / 2003- \\
2019\end{array}$ & $\begin{array}{l}\text { CDE, BST, } \\
\text { g/h, alpha }\end{array}$ & LB & Y & $\begin{array}{l}\text { Yes ( } \mathrm{N}=17 \\
\text { ongoing } \\
\text { publication) }\end{array}$ & $\begin{array}{l}\text { B - intrusive } M / S / A u \\
\text { components }\end{array}$ & Bordes et al., 2008; OMP & MAN, Saint-Germain-en-Laye (France) \\
\hline $\begin{array}{l}\text { Les } \\
\text { Peyrugues }\end{array}$ & Orniac & Rockshelter & $1986-2002$ & $5-9$ & LB & Y & Yes $(N=8)$ & $\begin{array}{l}\mathrm{L} \text { - intrusive } M / S \\
\text { components }\end{array}$ & $\begin{array}{l}\text { Allard, 1992; Ducasse, 2010; } \\
\text { Jaubert, } 2013\end{array}$ & MNP, Les Eyzies-de-Tayac (France) \\
\hline Mirande 2 & Nègrepelisse & Open-air & 2014 & . & LB & $\mathrm{N}$ & none & $\mathrm{E}$ & Langlais et al., 2016 & $\begin{array}{r}\text { PACEA laboratory, Bordeaux (France) - } \\
\text { temporary depot }\end{array}$ \\
\hline \multicolumn{11}{|l|}{ Agenais } \\
\hline Cassegros & Trentels & Cave & $1973-1985$ & 9 and 10 & $E B$ ? and LB & Y & $\begin{array}{l}\text { Yes }(\mathrm{N}=14 ; \\
\text { ongoing } \\
\text { publication) }\end{array}$ & $\begin{array}{c}\text { G - marginal intrusive } \\
M \text { component (top of } \\
\text { layer } 9 \text { ) }\end{array}$ & Le Tensorer, 1981; OMP & MNP, Les Eyzies-de-Tayac (France) \\
\hline \multicolumn{11}{|l|}{ Perigord } \\
\hline Chatenet & $\begin{array}{l}\text { St-Front-de- } \\
\text { Pradoux }\end{array}$ & Open-air & 1988 & . & LB & $\mathrm{N}$ & none & $\begin{array}{l}\text { G - marginal intrusive } \\
\text { Mousterian evidence }\end{array}$ & $\begin{array}{l}\text { Gaussen and Moissat, 1990; } \\
\text { Fourloubey, 1996, 1998; OMP }\end{array}$ & MNP, Les Eyzies-de-Tayac (France) \\
\hline Casserole & $\begin{array}{l}\text { Les Eyzies-de- } \\
\text { Tayac }\end{array}$ & Rockshelter & 1991-1993 & NA4-NA6 & EB and LB & Y & Yes $(N=4)$ & $\mathrm{E}$ & $\begin{array}{c}\text { Detrain et al., 1991; Morala, } \\
\text { 1993; Ducasse et al., 2020; } \\
\text { OMP }\end{array}$ & MNP, Les Eyzies-de-Tayac (France) \\
\hline \multicolumn{11}{|l|}{ Gironde } \\
\hline Birac III & $\begin{array}{l}\text { St-Sulpice-et- } \\
\text { Cameyrac }\end{array}$ & Open-air & 1960 & . & LB & $\mathrm{N}$ & none & $\begin{array}{c}\text { To determine - possible } \\
\text { Au component }\end{array}$ & Crochet, 1967; Lenoir, 1983 & PACEA laboratory, Bordeaux (France) \\
\hline \multicolumn{11}{|l|}{ Landes } \\
\hline Cabannes & $\begin{array}{l}\text { Brocas-les- } \\
\text { Forges }\end{array}$ & Open-air & 1998-1999 & . & LB & $\mathrm{N}$ & none & $\mathrm{E}$ & $\begin{array}{l}\text { Gellibert and Merlet, 2001; } \\
\text { Ducasse, } 2010\end{array}$ & $\begin{array}{r}\text { PACEA laboratory, Bordeaux (France) - } \\
\text { temporary depot }\end{array}$ \\
\hline Seyresse & Seyresse & Open-air & 1970 & . & LB? & $\mathrm{N}$ & none & $\mathrm{E}$ & $\begin{array}{l}\text { Ducasse and Langlais, 2008; } \\
\text { Ducasse, } 2010\end{array}$ & $\begin{array}{l}\text { SRA Nouvelle Aquitaine, excavations } \\
\text { storage depot, Hasparren (France) }\end{array}$ \\
\hline
\end{tabular}




\begin{tabular}{|c|c|c|c|c|c|c|c|c|c|c|}
\hline \multicolumn{11}{|c|}{ Languedoc-Pyrenees } \\
\hline Lassac & $\begin{array}{l}\text { Sallèles- } \\
\text { Cabardès }\end{array}$ & Open-air & 1973 & locus 1 & LB & $Y$ & $\begin{array}{c}\text { Yes ( } \mathrm{N}=3+ \\
\text { ongoing } \\
\text { analysis) }\end{array}$ & G & $\begin{array}{c}\text { Sacchi, 1986, 2003; Ducasse, } \\
\text { 2010; OMP }\end{array}$ & $\begin{array}{r}\text { Carcassonne (France), excavation storage } \\
\text { depot }\end{array}$ \\
\hline $\begin{array}{l}\text { Petite } \\
\text { grotte de } \\
\text { Bize }\end{array}$ & $\begin{array}{c}\text { Bize- } \\
\text { Minervois }\end{array}$ & Cave & $1927-1933$ & $\begin{array}{l}1 \text { (Helena) } \\
\text { and } 5 \\
\text { (Genson) }\end{array}$ & LB & $\mathrm{Y}$ & none & $\begin{array}{l}\text { B - ancient and recent } \\
\text { admixtures (excavation } \\
\text { and storage issues) }\end{array}$ & Sacchi, 1969, 1986 & $\begin{array}{r}\text { Béziers Museum and Palais des } \\
\text { Archevêques of Narbonne (France) }\end{array}$ \\
\hline $\begin{array}{l}\text { Les } \\
\text { Harpons }\end{array}$ & Lespugue & Rockshelter & $1912-1930$ & D & LB & $Y$ & Yes & $\begin{array}{l}\text { B - intrusive } M / S / G \\
\text { components }\end{array}$ & Ducasse et al., 2017 & $\begin{array}{l}\text { MAN, Saint-Germain-en-Laye; Lespugue } \\
\text { and Montmaurin Museums (France) }\end{array}$ \\
\hline Enlène & $\begin{array}{l}\text { Montesquieu- } \\
\text { Avantès }\end{array}$ & Cave & $1984-1990$ & EDG, layer 4 & LB & $Y$ & Yes & $\begin{array}{l}\text { B - intrusive } M / S / G \\
\text { components }\end{array}$ & $\begin{array}{c}\text { Clottes, 1989; Bégouën et al., } \\
2019\end{array}$ & $\begin{array}{r}\text { Pujol laboratory, Montesquieu-Avantès } \\
\text { (France) }\end{array}$ \\
\hline \multicolumn{11}{|c|}{ Basque Country } \\
\hline $\begin{array}{l}\text { Aitzbitarte } \\
\text { IV }\end{array}$ & Errenteria & Cave & $1960-1964$ & . & LB & $\mathrm{Y}$ & none & $\begin{array}{l}\text { B - intrusive } M / S \\
\text { component }\end{array}$ & $\begin{array}{l}\text { Utrilla, 1986, 1989; Ducasse and } \\
\text { Ruiz-Redondo, in prep }\end{array}$ & $\begin{array}{r}\text { Centro de Patrimonio Cultural Mueble de } \\
\text { Gipuzkoa (Irún, Spain) }\end{array}$ \\
\hline
\end{tabular}

Table 1. Detail of the studied sites, outlining the documented Badegoulian stages (EB: Early Badegoulian; LB: Late Badegoulian), the presence of bone and antler assemblages, the availability of ${ }^{14} \mathrm{C}$ AMS ages (*=report limited to the Badegoulian levels), the confidence level assigned to each industry (E: excellent; G: good; L: low; B: bad; Technocomplexe arcronym correspondence: Az=Azilian; M=Magdalenian; S=Solutrean; G=Gravettian; Au=Aurignacian) and the main location information (SRA: Service régional de l'archéologie; MAN: Musée d'Archéologie nationale; MNP: Musée national de Préhistoire). OMP: ongoing monograph publication. 


\section{Quercy}

1

3

Cuzoul de Vers
Cuzoul de Vers
Cuzoul de Vers
Cuzoul de Vers
Cuzoul de Vers
Cuzoul de Vers

$6 c^{\prime}$
6
15
18
19
$21 c$

Late Badegoulian
Late Badegoulian
Late Badegoulian
Late Badegoulian
Late Badegoulian
Late Badegoulian
Early Badegoulian

$$
\text { B2 }
$$

CZ85 J4 c21c \#1555

Cuzoul de Vers

Cuzoul de Vers

Early Badegoulian

Early Badegoulian

Cuzoul de Vers

Cuzoul de Vers

Cuzoul de Vers

Cuzoul de Vers

Cuzoul de Vers

Pégourié

Pégourié

Pégourié
B5
Upper Solutrean

Upper Solutrean

Upper Solutrean

Upper Solutrean

Upper Solutrean

Late Badegoulian-like

Late Badegoulian-like
Late Badegoulian-like

CZ86 E5 c29a \#1649

CZ86 14 c30 \#2472

CZ85 B4 c30 \#1291

CZ86 J4 c31 \#2049

Peg 257 c8b K5

$\# 3764$

Peg 283 c8c K6 \#3475

Antler

Antler

$8 c$

Bone

Bone

Bone

Burned

bone

Bone

tler$$
\begin{gathered}
\text { CZ84 K4 c6c' \#289 } \\
\text { non coordinated } \\
\text { ("vrac") }
\end{gathered}
$$$$
\text { B2 or B3 square }
$$$$
\text { E5 }
$$

CZ83 D4 c19 \#1772

$$
\text { D2 to D5 }
$$

CZ86 15 c22a \#636

CZ86 D5 c27 \#1192

\section{Antler}

Bone

Bone

Bone

Antler

Antler

Bone

Antler

Antler

(1)

Peg 341 K6 \#4312

Flaked antler
MSU diaphysis
MSU diaphysis
MSU diaphysis
Flake
Flake
MSU diaphysis
Knapped splinter
Flake

$18,640 \pm 71$

$18,730 \pm 110$

$18,730 \pm 100$

$19,020 \pm 110$

$18,590 \pm 110$

$18,860 \pm 110$

$19,280 \pm 120$

$18,920 \pm 110$

$19,150 \pm 110$

MSU diaphysis

Reindeer Metatarsal

MSU diaphysis

Reindeer Tibia

MSU diaphysis

$$
\text { Flake }
$$

Flake

Decorated single

beveled point using the "pseudo-excise" technique

$19,410 \pm 100$

$19,380 \pm 100$

$19,050 \pm 100$

$19,320 \pm 100$

$18,440 \pm 170$
Lyon-9074 (SacA-

28341) \& OxA-

24963

OxA-10955

(Lyon-1674)

OxA-10974

(Lyon-1676)

OxA-11118

(Lyon-1681)

Lyon-9076 (SacA-

28343)

Lyon-9075 (SacA-

28342)

22,990-22,495

OxA-10976

(Lyon-1678)

$23,428-22,960$ (76,2\%)

Lyon-9077 (SacA28344)

-9078 (SacA-

$23,691-23,602(4,0 \%)$ 28345)

OxA-11220

(Lyon-1682)

Lyon-10351

(SacA-33960)

Lyon-10352

(SacA-33961)

Lyon-10353

$23,196-22,626$

$23,735-23,531(22,6 \%)$

$23,430-22,994(72,8 \%)$

(SacA-33963)

Lyon-13121

(SacA-45471)

Lyon-13122

(SacA-45472)

$22,854-22,045$

OxA-35268

$17,960 \pm 90 \quad 22,090-21,454$
Ducasse et al. oberin Oberlin and Valladas 2012
Oberlin and Valladas 2012 Oberlin and Valladas 2012 Ducasse et al. Ducasse et al. 2014

Oberlin and Valladas 2012 Ducasse et al. 2014

Ducasse et al. 2014

Oberlin and Valladas 2012 Ducasse et al. 2014

Ducasse et al. 2014

Ducasse et al. 2014 Ducasse et al. 2014 Ducasse et al. 2019

Ducasse et al. 2019

Ducasse et al. 2019 


\begin{tabular}{|c|c|c|c|c|c|c|c|c|c|c|}
\hline 18 & Pégourié & $8 a$ & Late Badegoulian-like & Peg 395 K7 \#6070 & Antler & $\begin{array}{l}\text { Recycled single and } \\
\text { striated-beveled } \\
\text { point }\end{array}$ & $18,310 \pm 90$ & $22,424-22,070$ & OxA-35269 & $\begin{array}{r}\text { Ducasse et al. } \\
2019\end{array}$ \\
\hline 19 & $\begin{array}{l}\text { Petit Cloup } \\
\text { Barrat }\end{array}$ & $8 \mathrm{a} 1$ & Late Badegoulian-like & РCB05 U72 d25 \#608 & Bone & MSU diaphysis & $18,595 \pm 150$ & $22,925-22,271$ & Lyon-3366 (Poz) & $\begin{array}{r}\text { Ducasse et al. } \\
2011\end{array}$ \\
\hline 20 & $\begin{array}{l}\text { Petit Cloup } \\
\text { Barrat }\end{array}$ & 4 & Late Badegoulian-like & PCB08 R70D d3 \#91 & Antler & Flake & $17,800 \pm 80$ & $21,933-21,370$ & $\begin{array}{c}\text { Lyon } 10856 \text { (SacA } \\
\text { 36272) }\end{array}$ & $\begin{array}{r}\text { Chauvière et al. } \\
2017\end{array}$ \\
\hline 21 & $\begin{array}{l}\text { Petit Cloup } \\
\text { Barrat }\end{array}$ & 4 & Late Badegoulian-like & $\begin{array}{l}\text { PCB08 P72A d20 } \\
\quad \# 680\end{array}$ & Antler & $\begin{array}{l}\text { "Arciform" artifact } \\
\text { rough-out }\end{array}$ & $17,720 \pm 90$ & $21,855-21,094$ & OxA 29408 & $\begin{array}{r}\text { Chauvière et al. } \\
2017\end{array}$ \\
\hline \multicolumn{11}{|c|}{$\begin{array}{l}\text { Dordogne- } \\
\text { Poitou }\end{array}$} \\
\hline 22 & Casserole & NA4 & Late Badegoulian & 014b \#1 & Antler & Flake & $17,760 \pm 100$ & $21,942-21,165$ & $\begin{array}{l}\text { Lyon-13948 } \\
\text { (SacA-48955) }\end{array}$ & $\begin{array}{r}\text { Ducasse et al. } \\
2020\end{array}$ \\
\hline 23 & Casserole & NA5 & Late Badegoulian & N15d \#34 & Antler & Flake & $18,100 \pm 80$ & $22,262-21,842$ & Lyon-13307 (GrA) & $\begin{array}{r}\text { Ducasse et al. } \\
2020\end{array}$ \\
\hline 24 & Casserole & NA6 & Early Badegoulian & Q12d & Bone & $\begin{array}{l}\text { Unworked humerus } \\
\text { (diaphysis; horse } \\
\text { size) }\end{array}$ & $18,755 \pm 50$ & $22,911-22,480$ & $\begin{array}{l}\text { Lyon-14316 } \\
\text { (GrM) }\end{array}$ & $\begin{array}{r}\text { Ducasse et al. } \\
2020\end{array}$ \\
\hline 25 & Casserole & NA6 & Early Badegoulian & R14b $(Z=93,2)$ & Bone & $\begin{array}{l}\text { Unworked reindeer } \\
\text { cotyloid cavity }\end{array}$ & $19,110 \pm 70$ & $23,171-22,909$ & $\begin{array}{l}\text { Lyon-14315 } \\
\text { (GrM) }\end{array}$ & $\begin{array}{r}\text { Ducasse et al. } \\
2020\end{array}$ \\
\hline 26 & Casserole & NA7 & Upper Solutrean & K10 a \#52 & $\begin{array}{l}\text { Burned } \\
\text { bone }\end{array}$ & Coxal (horse size) & $19,300 \pm 120$ & $\begin{array}{l}23,737-23,524(21,9 \%) \\
23,438-22,973(73,5 \%)\end{array}$ & Lyon-9944 & $\begin{array}{r}\text { Ducasse et al. } \\
2020\end{array}$ \\
\hline 27 & Casserole & NA7b & Upper Solutrean & K10 b \#55 & $\begin{array}{l}\text { Burned } \\
\text { bone }\end{array}$ & . & $19,020 \pm 110$ & $23,169-22,574$ & Lyon-9945 & $\begin{array}{r}\text { Ducasse et al. } \\
2020\end{array}$ \\
\hline 28 & $\begin{array}{l}\text { Taillis-des- } \\
\text { Coteaux }\end{array}$ & AG-V & Late Badegoulian & . & Bone & . & $18,140 \pm 85$ & $22,307-21,891$ & Lyon-2639 & $\begin{array}{r}\text { Primault et al. } \\
2010\end{array}$ \\
\hline \multicolumn{11}{|c|}{$\begin{array}{l}\text { Bourgogne- } \\
\text { Massif } \\
\text { Central }\end{array}$} \\
\hline 29 & $\begin{array}{l}\text { Oisy-Mont St. } \\
\text { Aubin }\end{array}$ & 3 & Late Badegoulian & . & Bone & . & $17,810 \pm 110$ & $22,016-21,264$ & $\begin{array}{c}\text { Ly-6398 (SacA- } \\
17475)\end{array}$ & $\begin{array}{r}\text { Debout et al. } \\
2012\end{array}$ \\
\hline 30 & $\begin{array}{l}\text { Oisy-Mont St. } \\
\text { Aubin }\end{array}$ & 3 & Late Badegoulian & . & Bone & . & $17,820 \pm 120$ & $22,038-21,236$ & $\begin{array}{l}\text { Ly-4622 (SacA- } \\
9685)\end{array}$ & $\begin{array}{r}\text { Debout et al. } \\
2012\end{array}$ \\
\hline 31 & $\begin{array}{l}\text { Oisy-Mont St. } \\
\text { Aubin }\end{array}$ & 4 & Late Badegoulian & . & Bone & . & $18,050 \pm 120$ & $\begin{array}{c}22,280-21,662(89,1 \%) \\
21,621-21467(6,4 \%)\end{array}$ & $\begin{array}{l}\text { Ly-6399 (SacA- } \\
17476)\end{array}$ & $\begin{array}{r}\text { Debout et al. } \\
2012\end{array}$ \\
\hline 32 & Contrée-Viallet & 3 & Late Badegoulian & . & Bone & Horse & $17,610 \pm 70$ & $\begin{array}{c}21,670-21,605(1,7 \%) \\
21,481-20,968(93,7 \%)\end{array}$ & Beta-377947 & Lafarge 2014 \\
\hline 33 & Contrée-Viallet & 3 & Late Badegoulian & . & Bone & Horse & $17,600 \pm 70$ & $\begin{array}{c}21,640-21,630(0,2 \%) \\
21,478-20,953(95,3 \%)\end{array}$ & Beta-377948 & Lafarge 2014 \\
\hline
\end{tabular}




\begin{tabular}{|c|c|c|c|c|c|c|c|c|c|c|}
\hline 34 & Blot & 15 & Late Badegoulian & J8 15-41 & Teeth & . & $18,000 \pm 80$ & $\begin{array}{c}22,155-21,675(90,2 \%) \\
21,600-21,468(5,2 \%)\end{array}$ & $\begin{array}{c}\text { GrA-17337 (Lyon- } \\
1337 \text { ) }\end{array}$ & $\begin{array}{r}\text { BANADORA; } \\
\text { Banks et al. } 2019\end{array}$ \\
\hline 35 & Blot & 9 & Late Badegoulian & K4 9-11 & Teeth & . & $17,850 \pm 80$ & $21,965-21,409$ & $\begin{array}{c}\text { GrA-17339 (Lyon- } \\
1336)\end{array}$ & $\begin{array}{r}\text { BANADORA; } \\
\text { Banks et al. } 2019\end{array}$ \\
\hline 36 & Cottier & $\|$ & Late Badegoulian & . & unknown & . & $17,910 \pm 70$ & $22,012-21,449$ & Beta-377946 & Lafarge 2014 \\
\hline 37 & Rond du Barry & $\mathrm{F} 2$ & Late Badegoulian-like & $3 C \# 539$ & Antler & Fragment & $17,490 \pm 80$ & $21,377-20,905$ & Beta-297899 & Raynal et al. 2014 \\
\hline 38 & Rond du Barry & $\mathrm{F} 2$ & Late Badegoulian-like & F14 & Antler & Fragment & $17,680 \pm 70$ & $21,760-21,071$ & Beta-297895 & Raynal et al. 2014 \\
\hline 39 & Rond du Barry & $\mathrm{F} 2$ & Late Badegoulian-like & E13 \#77 & Antler & Fragment & $17,720 \pm 80$ & $21,839-21,123$ & Beta-306179 & Raynal et al. 2014 \\
\hline 40 & Rond du Barry & $\mathrm{E}$ & Late Badegoulian-like & J13 \#1 & Antler & Flake & $17,960 \pm 70$ & $\begin{array}{l}22,080-21,656(85,4 \%) \\
21,625-21,462(10,1 \%)\end{array}$ & Beta-297897 & Rémy, 2013 \\
\hline \multicolumn{11}{|c|}{$\begin{array}{l}\text { Languedoc- } \\
\text { Pyrenees }\end{array}$} \\
\hline 41 & Lassac & locus 1 & Late Badegoulian & M6 CX rel.6 & Antler & Flake & $17,400 \pm 110$ & $21,390-20,750$ & $\begin{array}{c}\text { Lyon-6417 (SacA- } \\
17494) \\
\text { Lyon-6418 (SacA- }\end{array}$ & $\begin{array}{r}\text { Pétillon and } \\
\text { Ducasse } 2012 \\
\text { Pétillon and }\end{array}$ \\
\hline 42 & Lassac & locus 1 & Late Badegoulian & W section & Antler & Flake & $17,530 \pm 100$ & $21,447-20,883$ & $\begin{array}{c}17495) \\
\text { Lyon-6419 (SacA- }\end{array}$ & Ducasse 2012 \\
\hline 44 & Lassac & locus 1 & Late Badegoulian & L6 rel8 & Antler & $\begin{array}{l}\text { Wedge } \\
\text { Sectioned base of } \\
\text { shed antler }\end{array}$ & $17,420 \pm 110$ & $21,396-20,790$ & 17496) & This paper \\
\hline & Les Harpons & D & & HARP-1 & Antler & (chopping) & $18,450 \pm 100$ & $22,556-22,145$ & OxA-26876 & 2017 \\
\hline 45 & Les Harpons & $\mathrm{D}$ & $\begin{array}{l}\text { Early/Late Badegoulian- } \\
\text { like }\end{array}$ & HARP-3 & Antler & Flake & $18,960 \pm 110$ & $23,070-22,535$ & OXA-26878 & $\begin{array}{l}\text { Ducasse et al. } \\
2017\end{array}$ \\
\hline
\end{tabular}

Table 2. AMS ${ }^{14} \mathrm{C}$ dates used in Figure 2 and covering the entire time span of the French Badegoulian, including the Solutrean-to-Badegoulian transition (MSU: mediumsized ungulate). Calibration was carried out with the OxCal program (v4.4.2: Bronk Ramsey, 2020) using the IntCal20 calibration curve (Reimer et al., 2020). 


\begin{tabular}{|c|c|c|c|c|c|c|c|c|c|c|c|}
\hline & Country & Site & Level/Sector & $\begin{array}{l}\text { Cultural } \\
\text { attribution }\end{array}$ & Labelling & Material & $\begin{array}{l}\text { Nature of } \\
\text { sample }\end{array}$ & $\begin{array}{l}\text { Uncalibrated } \\
\text { age (BP) }\end{array}$ & $\begin{array}{l}\text { Calibrated age } \\
\quad(B P, 2 \sigma)\end{array}$ & Lab Code & Reference \\
\hline 1 & Spain & Llonin & $\begin{array}{l}\text { Level III } \\
\text { (gallery) }\end{array}$ & $\begin{array}{c}\text { Late } \\
\text { Badegoulian }\end{array}$ & LLO-71 & Charcoal & Ericacea & $17,480 \pm 75$ & $21,366-20,902$ & OxA-26042 & $\begin{array}{r}\text { Rasilla Vives et } \\
\text { al., } 2019\end{array}$ \\
\hline 2 & Spain & Llonin & $\begin{array}{l}\text { Level III } \\
\text { (gallery) }\end{array}$ & $\begin{array}{c}\text { Late } \\
\text { Badegoulian }\end{array}$ & LLO-70 & Charcoal & Ericacea & $17,610 \pm 90$ & $21,712-20,955$ & OxA-26041 & $\begin{array}{r}\text { Rasilla Vives et } \\
\text { al., } 2019\end{array}$ \\
\hline 3 & Spain & Llonin & $\begin{array}{l}\text { Level III } \\
\text { (gallery) }\end{array}$ & $\begin{array}{c}\text { Late } \\
\text { Badegoulian }\end{array}$ & LLO-68 & Charcoal & Juniperus & $17,650 \pm 130$ & $21,829-20,950$ & OxA-26338 & $\begin{array}{r}\text { Rasilla Vives et } \\
\text { al., } 2019\end{array}$ \\
\hline 4 & Spain & Llonin & $\begin{array}{l}\text { Level III } \\
\text { (gallery) }\end{array}$ & $\begin{array}{l}\text { Late } \\
\text { Badegoulian }\end{array}$ & LLO-71 & Charcoal & Juniperus & $17,920 \pm 80$ & $22,033-21,445$ & OxA-26340 & $\begin{array}{r}\text { Rasilla Vives et } \\
\text { al., } 2019\end{array}$ \\
\hline 5 & Spain & Llonin & $\begin{array}{l}\text { Level III } \\
\text { (gallery) }\end{array}$ & $\begin{array}{c}\text { Late } \\
\text { Badegoulian }\end{array}$ & LLO-31 & Bone & & $18,100 \pm 90$ & $22,286-21,814$ & OxA-X-2559-11 & $\begin{array}{r}\text { Rasilla Vives et } \\
\text { al., } 2019\end{array}$ \\
\hline 6 & Spain & Llonin & $\begin{array}{l}\text { Level III } \\
\text { (gallery) }\end{array}$ & $\begin{array}{l}\text { Late } \\
\text { Badegoulian }\end{array}$ & LLO-69 & Charcoal & Fabacea & $18,345 \pm 75$ & $\begin{array}{l}22,435-22,123 \\
23,734-23,532\end{array}$ & OxA-26339 & $\begin{array}{r}\text { Rasilla Vives et } \\
\text { al., } 2019\end{array}$ \\
\hline 7 & Spain & Llonin & $\begin{array}{l}\text { Level IV } \\
\text { (gallery) }\end{array}$ & $\begin{array}{l}\text { Upper } \\
\text { Solutrean }\end{array}$ & LLO-28 & Bone & & $19,300 \pm 110$ & $\begin{array}{c}(20.7 \%) \\
23,429-22,976 \\
(74.7 \%)\end{array}$ & OxA-22700 & $\begin{array}{r}\text { Rasilla Vives et } \\
\text { al., } 2019\end{array}$ \\
\hline 8 & Spain & Llonin & $\begin{array}{l}\text { Level IV } \\
\text { (gallery) }\end{array}$ & $\begin{array}{c}\text { Upper } \\
\text { Solutrean }\end{array}$ & LLO-27 & Bone & & $19,330 \pm 100$ & $\begin{array}{c}23,737-23,526 \\
(24.3 \%) \\
23,436-23,001 \\
(71.2 \%)\end{array}$ & OxA-22699 & $\begin{array}{r}\text { Rasilla Vives et } \\
\text { al., } 2019\end{array}$ \\
\hline 9 & Spain & Llonin & $\begin{array}{l}\text { Level IV } \\
\text { (gallery) }\end{array}$ & $\begin{array}{l}\text { Upper } \\
\text { Solutrean }\end{array}$ & LLO-26 & Bone & e & $19,480 \pm 110$ & $23,779-23,145$ & OxA-22698 & $\begin{array}{r}\text { Rasilla Vives et } \\
\text { al., } 2019\end{array}$ \\
\hline 10 & Switzerland & $\begin{array}{l}\text { Kastelhöhle- } \\
\text { Nord }\end{array}$ & middle level & $\begin{array}{l}\text { Early } \\
\text { Badegoulian- } \\
\text { like }\end{array}$ & UPN-221 & Bone & $\begin{array}{c}\text { Reindeer } \\
\text { metatarsal, cut- } \\
\text { marked }\end{array}$ & $19,140 \pm 80$ & $23,263-22,910$ & $\begin{array}{c}\text { OxA-V-2793- } \\
57 \mathrm{C}\end{array}$ & $\begin{array}{r}\text { Reade et al., } \\
2020\end{array}$ \\
\hline 11 & Switzerland & $\begin{array}{l}\text { Kastelhöhle- } \\
\text { Nord }\end{array}$ & middle level & $\begin{array}{l}\text { Early } \\
\text { Badegoulian- } \\
\quad \text { like }\end{array}$ & UPN-222 & Bone & $\begin{array}{l}\text { Reindeer tibia, } \\
\text { cut-marked }\end{array}$ & $19,200 \pm 90$ & $\begin{array}{c}23,683-23,610 \\
(4,3 \%) \\
23,355-22,936 \\
(91,2 \%)\end{array}$ & $\begin{array}{c}\text { OxA-V-2797- } \\
20 C\end{array}$ & $\begin{array}{r}\text { Reade et al., } \\
2020\end{array}$ \\
\hline 12 & Switzerland & $\begin{array}{l}\text { Kastelhöhle- } \\
\text { Nord }\end{array}$ & middle level & $\begin{array}{l}\text { Early } \\
\text { Badegoulian- } \\
\quad \text { like }\end{array}$ & UPN-223 & Bone & $\begin{array}{c}\text { Reindeer } \\
\text { phalanx } 1 \text {, cut- } \\
\text { marked }\end{array}$ & $19,110 \pm 90$ & $23,280-22,880$ & $\begin{array}{c}\text { OxA-V-2804- } \\
43 C \\
\text { OxA-V-3002- } \\
12 C\end{array}$ & $\begin{array}{r}\text { Reade et al., } \\
2020 \\
\text { Reade et al., } \\
2020\end{array}$ \\
\hline
\end{tabular}

Table 3. Available AMS ${ }^{14} \mathrm{C}$ ages for the Late Badegoulian assemblages from Llonin Cave, level III (Spain) and the Early Badegoulian-like assemblages from KastelhöhleNord, middle archaeological layer (Switzerland). Calibration was carried out with the OxCal program (v4.4.2: Bronk Ramsey, 2020) using the IntCal20 calibration curve (Reimer et al., 2020). 